Review

\title{
The Yield of the Thermal Engines
}

\author{
${ }^{1}$ Nicolae Petrescu and ${ }^{2}$ Florian Ion Tiberiu Petrescu \\ ${ }^{I}$ Bucharest University, Bucharest, (CE), Romania \\ ${ }^{2}$ ARoTMM-IFToMM, Bucharest Polytechnic University, Bucharest, (CE), Romania
}

Article history

Received: 08-05-2019

Revised: 09-05-2019

Accepted: 13-05-2019

Corresponding Author: Florian Ion T. Petrescu ARoTMM-IFToMM, Bucharest Polytechnic University, Bucharest, (CE), Romania Email: fitpetrescu@gmail.com

\begin{abstract}
This paper presents an algorithm for determining the dynamic parameters of the main classic mechanism of internal combustion engines. It shows the distribution of forces (on the main engine mechanism) to internal combustion engines. With these forces and together with the kinematic coupling speeds, the efficiency of the thermal engine is determined. The method applies separately for two distinct situations: When the engine is working as a compressor and as a motor mechanism. For the two separate cases, two independent formulas for engine efficiency are obtained. These relationships are then calculated in terms of Otto's mechanical efficiency in four-stroke, two-stroke and fourstroke. The final power of the engine is obtained taking into account the thermal efficiency of the Carnot cycle.
\end{abstract}

Keywords: Robots, Mechatronic Systems, Structure, Dynamics, Dynamics Systems, Machines, Dynamic Factors, Engines, Thermal Engines, Yield

\section{Introduction}

The old gasoline engine wears us every day for almost 150 years. The old Otto engine (and his brother, Diesel) is today: Younger, more robust, more dynamic, stronger, more economical, more independent, more reliable, quieter, cleaner, more compact, more sophisticated and especially necessary. At global level, we can eliminate approximately 60,000 cars annually. But every year there are millions of other cars.

The planet now supports about a billion vehicles in circulation. Even if we stop the total production of thermal engines, we will still need 10,000 years to eliminate the total car fleet. Electric current is still largely produced by burning hydrocarbons, which makes hydrocarbon losses higher when using electric motors. When we have electricity obtained only from green, sustainable and renewable energy sources, only electric motors can be introduced gradually.

Otto and diesel engines are today the best solution for transporting our daily work together with electric and reaction engines.

For these reasons, it is imperative that you can accurately calculate the engine's efficiency to be able to grow permanently.

Today we witness a real battle between internal and electric combustion engines, for priority in their application to cars and vehicles of any kind. The electric engine boasts that it is more electronic, more noxious, quieter and that he is now in turn and his grandfather Otto and Diesel would have to get out of his way and not stop them that he is young and has a beautiful future ahead. The Otto engine tells the electrician to wait for a little because he does not yet have the batteries, they are heavily loaded, difficult in a long time, in special conditions, plus they do not have enough autonomy with all the promises and efforts made by experts over the last 50 years. A totally electric car includes only cables and circuits, which, if they take fire, are harder or harder. Pollution from battery cells is very high and even more dangerous than gas, oil, gas, alcohol, or hydrogen. Do not rush so hard to take your full seat, that we have long left you to replace us in public transport, by wire, by trolley, by tram, by subway, by trains, by trucks and buses, that is, where it was necessary to supply the batteries because the power is constantly on the go. The idea of fueling any vehicle equipped with a direct-on-the-go electric motor is not yet sustainable, although some photovoltaic cell capacity has been shown to be somewhat awkward but inadequate to a full supply and especially at night in bad weather. It's been a long time ago that a beautiful dream begun by Tesla started to feed all the vehicles wirelessly, but if Wizard Nikola could launch such projects 100 years ago when electronics did not even exist, we do not know if it really does not affect living beings, we do not know how it acted, but today we know clearly that a large amount of wireless energy transmission can only 
be done by concentrated electromagnetic waves, for example by microwaves, but which as a side effect fry everything in their way like a microwave oven. The reluctant desire of some to introduce G5 microwave wireless systems could lead to the rapid disappearance of life on Earth. We hoped it would not happen even now and ever. Such attempts have often been made but only for the construction of weapons and militant experiments. An ancient attempt to transmit energy from Cosmic Space to Terra through microwaves in an isolated location in the United States has resulted in severe damage to a sheepmeat in that area and shepherds.

On the other hand, the use and production of free energy is still under study and if in the future it could be an infinitely friendly energy source, today it is not yet well established and magnetic motors of any type already studied for over 25 years and permanently upgraded have not resulted from the rapid demagnetization of the used materials, which is not publicly communicated but is well known to those skilled in the art, so that stories with magnetic and free energy remain in fact only fairy tales which we can not yet seriously rely on in practice. Water engines deserve special attention, including those with salt water, but also those with hydrogen. They have all the prospects ahead, but they still need time to grow big. Electric motors used in aerospace, in reality, need a classic energy source yet and then we will burn all gas or oil products, or possibly hydrogen (Antonescu and Petrescu, 1985; 1989; Antonescu et al., 1985a; 1985b; 1986; 1987; 1988; 1994; 1997; 2000a; 2000b; 2001; Aversa et al., 2017a; 2017b; 2017c; 2017d; 2017e; 2016a; 2016b; 2016c; 2016d; 2016e; 2016f; 2016g; 2016h; 2016i; 2016j; 2016k; 2016l; 2016m; 2016n; 2016o; Cao et al., 2013; Dong et al., 2013; Comanescu, 2010; Franklin, 1930; He et al., 2013; Lee, 2013; Lin et al., 2013; Liu et al., 2013; Padula and Perdereau, 2013; Perumaal and Jawahar, 2013; Petrescu, 2011; 2015a; 2015b; Petrescu and Petrescu, 1995a; 1995b; 1997a; 1997b; 1997c; 2000a; 2000b; 2002a; 2002b; 2003; 2005a; 2005b; 2005c; 2005d; 2005e; 2011a; 2011b; 2012a; 2012b; 2013a; 2013b; 2013c; 2013d; 2013e; 2016a; 2016b; 2016c; Petrescu et al., 2009; 2016; 2017a; 2017b; 2017c; 2017d; 2017e; 2017f; 2017g; 2017h; 2017i; $2017 \mathrm{j} ; 2017 \mathrm{k} ; 2017 \mathrm{l} ; 2017 \mathrm{~m} ; 2017 \mathrm{n} ; 2017 \mathrm{o} ; 2017 \mathrm{p}$; 2017q; 2017r; 2017s; 2017t; 2017u; 2017v; 2017w; 2017x; 2017y; 2017z; 2017aa; 2017ab; 2017ac; 2017ad; 2017ae; 2018a; 2018b; 2018c; 2018d; 2018e; 2018f; 2018g; 2018h; 2018i; 2018j; 2018k; 2018l; 2018m; 2018n; Rulkov et al., 2016; Agarwala, 2016; Babayemi, 2016; Gusti and Semin, 2016; Mohamed et al., 2016; Wessels and Raad, 2016; Maraveas et al., 2015; Khalil, 2015; Rhode-Barbarigos et al., 2015; Takeuchi et al., 2015; Li et al., 2015; Vernardos and Gantes, 2015; Bourahla and Blakeborough, 2015; Stavridou et al., 2015; Ong et al., 2015; Dixit and Pal, 2015; Rajput et al., 2016;
Rea and Ottaviano, 2016; Zurfi and Zhang, 2016 a-b; Zheng and Li, 2016; Buonomano et al., 2016a; 2016b; Faizal et al., 2016; Ascione et al., 2016; Elmeddahi et al., 2016; Calise et al., 2016; Morse et al., 2016; Abouobaida, 2016; Rohit and Dixit, 2016; Kazakov et al., 2016; Alwetaishi, 2016; Riccio et al., 2016a; 2016b; Iqbal, 2016; Hasan and El-Naas, 2016; Al-Hasan and AlGhamdi, 2016; Jiang et al., 2016; Sepúlveda, 2016; Martins et al., 2016; Pisello et al., 2016; Jarahi, 2016; Mondal et al., 2016; Mansour, 2016; Al Qadi et al., 2016b; Campo et al., 2016; Samantaray et al., 2016; Malomar et al., 2016; Rich and Badar, 2016; Hirun, 2016; Bucinell, 2016; Nabilou, 2016b; Barone et al., 2016; Chisari and Bedon, 2016; Bedon and Louter, 2016; Santos and Bedon, 2016; Minghini et al., 2016; Bedon, 2016; Jafari et al., 2016; Chiozzi et al., 2016; Orlando and Benvenuti, 2016; Wang and Yagi, 2016; Obaiys et al., 2016; Ahmed et al., 2016; Jauhari et al., 2016; Syahrullah and Sinaga, 2016; Shanmugam, 2016; Jaber and Bicker, 2016; Wang et al., 2016; Moubarek and Gharsallah, 2016; Amani, 2016; Shruti, 2016; Pérezde León et al., 2016; Mohseni and Tsavdaridis, 2016; Abu-Lebdeh et al., 2016; Serebrennikov et al., 2016; Budak et al., 2016; Augustine et al., 2016; Jarahi and Seifilaleh, 2016; Nabilou, 2016a; You et al., 2016; AL Qadi et al., 2016a; Rama et al., 2016; Sallami et al., 2016; Huang et al., 2016; Ali et al., 2016; Kamble and Kumar, 2016; Saikia and Karak, 2016; Zeferino et al., 2016; Pravettoni et al., 2016; Bedon and Amadio, 2016; Chen and $\mathrm{Xu}, 2016$; Mavukkandy et al., 2016; Yeargin et al., 2016; Madani and Dababneh, 2016; Alhasanat et al., 2016; Elliott et al., 2016; Suarez et al., 2016; Kuli et al., 2016; Waters et al., 2016; Montgomery et al., 2016; Lamarre et al., 2016; Daud et al., 2008; Taher et al., 2008; Zulkifli et al., 2008; Pourmahmoud, 2008; Pannirselvam et al., 2008; Ng et al., 2008; El-Tous, 2008; Akhesmeh et al., 2008; Nachiengtai et al., 2008; Moezi et al., 2008; Boucetta, 2008; Darabi et al., 2008; Semin and Bakar, 2008; Al-Abbas, 2009; Abdullah et al., 2009; Abu-Ein, 2009; Opafunso et al., 2009; Semin et al., 2009a; 2009b; 2009c; Zulkifli et al., 2009; Marzuki et al., 2015; Bier and Mostafavi, 2015; Momta et al., 2015; Farokhi and Gordini, 2015; Khalifa et al., 2015; Yang and Lin, 2015; Chang et al., 2015; Demetriou et al., 2015; Rajupillai et al., 2015; Sylvester et al., 2015; Ab-Rahman et al., 2009; Abdullah and Halim, 2009; Zotos and Costopoulos, 2009; Feraga et al., 2009; Bakar et al., 2009; Cardu et al., 2009; Bolonkin, 2009a; 2009b; Nandhakumar et al., 2009; Odeh et al., 2009; Lubis et al., 2009; Fathallah and Bakar, 2009; Marghany and Hashim, 2009; Kwon et al., 2010; Aly and Abuelnasr, 2010; Farahani et al., 2010; Ahmed et al., 2010; Kunanoppadon, 2010; Helmy and ElTaweel, 2010; Qutbodin, 2010; Pattanasethanon, 2010; Fen et al., 2011; Thongwan et al., 2011; Theansuwan and 
Triratanasirichai, 2011; Al Smadi, 2011; Tourab et al., 2011; Raptis et al., 2011; Momani et al., 2011; Ismail et al., 2011; Anizan et al., 2011; Tsolakis and Raptis, 2011; Abdullah et al., 2011; Kechiche et al., 2011; Ho et al., 2011; Rajbhandari et al., 2011; Aleksic and Lovric, 2011; Kaewnai and Wongwises, 2011; Idarwazeh, 2011; Ebrahim et al., 2012; Abdelkrim et al., 2012; Mohan et al., 2012; Abam et al., 2012; Hassan et al., 2012; Jalil and Sampe, 2013; Jaoude and El-Tawil, 2013; Ali and Shumaker, 2013; Zhao, 2013; El-Labban et al., 2013; Djalel et al., 2013; Nahas and Kozaitis, 2013; Petrescu and Petrescu, 2014a; 2014b; 2014c; 2014d; 2014e; 2014f; 2014g; 2014h; 2014i; 2015a; 2015b; 2015c; 2015d; 2015e; 2016a; 2016b; 2016c; 2016d; Fu et al., 2015; Al-Nasra et al., 2015; Amer et al., 2015; Sylvester et al., 2015b; Kumar et al., 2015; Gupta et al., 2015; Stavridou et al., 2015b; Casadei, 2015; Ge and $\mathrm{Xu}, 2015$; Moretti, 2015; Wang et al., 2015).

At the risk of alerting the lovers of electric motors, we are going to reveal a secret here to clarify some important aspects about the future of the thermal engines.

Recently the oil reserves of the planet have multiplied by the discovery of new oil fields and with the green or nuclear energy programs already massively implemented and with public electric transport, oil has been greatly saved, so that if in 1970-1980 when the energy crisis and especially the fossil fuels began to predict a rapid exhaustion of all fossil fuels, today we have real reserves of oil for another 100-200 years under the conditions of their rational use.

But more than that, it has been discovered and already started to use shale gas (deep-sea), which has increased the reserve of already existent gas to about 2000 years for Terra.

Some say it will be sad to drive cars only with gas, but they have already grown so much and so are heavy passenger airplanes. In addition, the future sounds good for Otto and even Diesel, because today there are technological processes to turn the gas into any desired type of fuel, gasoline, diesel ... There have already been installed worldwide three major conversion plants, can process huge amounts of gas by turning it into any kind of classic fuel, gasoline, diesel ... Such plants will multiply quickly and then gas reserves for another two thousand years will actually mean a gas reserve and diesel for another two thousand years for the planet. Under these conditions, the electric engine will have to come in a package with many real improvements to replace Otoo and Diesel on future cars.

So we can say that the struggle between them continues and will be even sorer in the future.

\section{Presents the Algorithm for the Otto Engine in Compressor System}

It presents an algorithm for determining the dynamic parameters of the internal combustion engine. It shows the distribution of forces (on the main engine mechanism) to internal combustion engines. With these forces and together with the kinematic coupling speeds, the efficiency of the thermal engine is determined.

The method applies separately for two distinct situations: when the engine is working on a compressor and the engine. For the two separate cases, two independent formulas for engine efficiency are obtained. It starts with the main engine mechanism in the compressor system (when the engine is operated from the crank, Fig. 1).

Now we will follow the distribution of forces in this case (Fig. 1).

The engine force $F_{m}$, perpendicular to $B$ on the crank 1, is divided into two components: $F_{n}$ and $F_{t}$.

The normal force, $F_{n}$, is transmitted along the stem (connecting rod) from point $B$ to point $C$.

The tangential force, $F_{t}$, is a rotating force that rotated the rod (element 2 ).

The force $F_{n}$ (normal) at $C$ is divided into two components: Fu and FR. The useful force, Fu, moves the piston and the radial force, $F_{R}$, presses the cylinder of the cylinder into the piston.

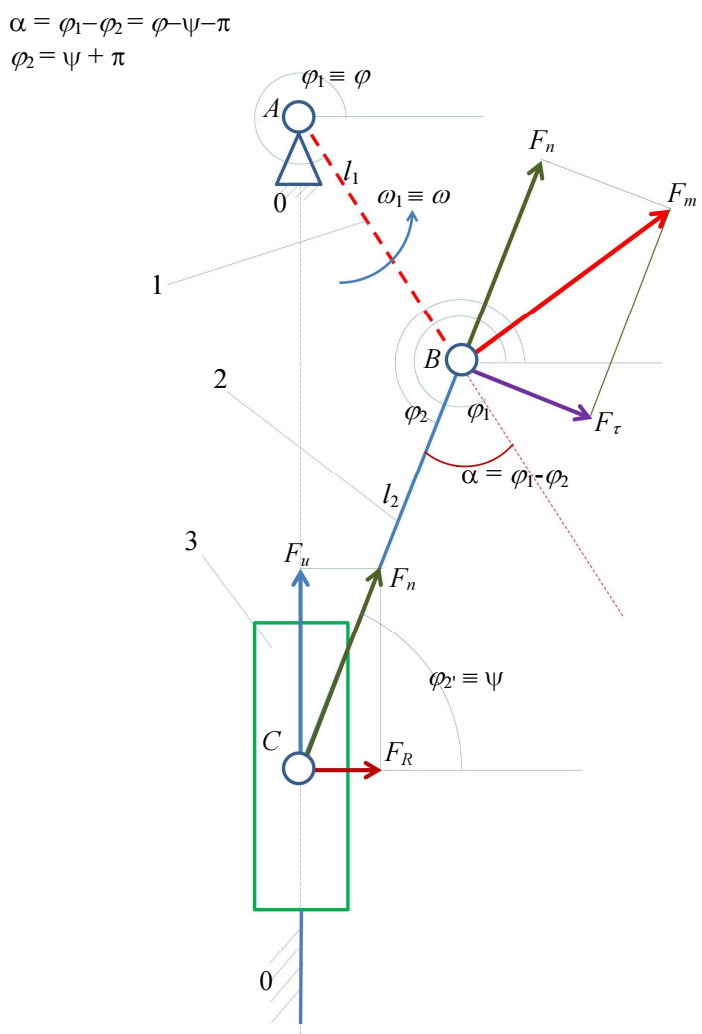

Fig. 1: The forces distribution in engine mechanism, when it is operated of the crank (element 1) 
The following calculation relationships can be written (1):

$$
\begin{aligned}
& \left\{\begin{array}{l}
F_{\tau}=F_{m} \cdot \cos \left(\varphi_{1}-\varphi_{2}\right) \\
F_{n}=F_{m} \cdot \sin \left(\varphi_{1}-\varphi_{2}\right)
\end{array} ;\right. \\
& \sin \left(\varphi_{1}-\varphi_{2}\right)=\sin (\varphi-\psi-\pi)=\sin (\psi-\varphi) \\
& \int F_{n}=F_{m} \cdot \sin (\psi-\varphi) \\
& F_{u}=F_{n} \cdot \sin \psi=F_{m} \cdot \sin \psi \cdot \sin (\psi-\varphi) \\
& y_{C}=l_{1} \cdot \sin \varphi-l_{2} \cdot \sin \psi \\
& v_{C} \equiv \dot{y}_{C}=l_{1} \cdot \cos \varphi \cdot \dot{\varphi}-l_{2} \cdot \cos \psi \cdot \dot{\psi} \\
& =l_{1} \cdot \cos \varphi \cdot \dot{\varphi}-l_{2} \cdot \cos \psi \cdot \lambda \cdot \frac{\sin \varphi}{\sin \psi} \cdot \dot{\varphi} \\
& =\frac{l_{1} \cdot \dot{\varphi}}{\sin \psi} \cdot(\sin \psi \cdot \cos \varphi-\sin \varphi \cdot \cos \psi) \\
& =\frac{l_{1} \cdot \sin (\psi-\varphi) \cdot \omega}{\sin \psi} \\
& P_{c} \equiv P_{m}=F_{m} \cdot v_{m}=F_{m} \cdot l_{1} \cdot \omega ; \\
& P_{u}=F_{u} \cdot v_{C}= \\
& =F_{m} \cdot \sin \psi \cdot \sin (\psi-\varphi) \cdot \frac{l_{1} \cdot \sin (\psi-\varphi) \cdot \omega}{\sin \psi} \\
& P_{u}=F_{m} \cdot l_{1} \cdot \omega \cdot \sin ^{2}(\psi-\varphi) \\
& \eta_{i}^{c}=\frac{P_{u}}{P_{c}}=\frac{F_{m} \cdot l_{1} \cdot \omega \cdot \sin ^{2}(\psi-\varphi)}{F_{m} \cdot l_{1} \cdot \omega} \\
& =\sin ^{2}(\psi-\varphi)=\sin ^{2} \beta, \text { with }: \beta=\psi-\varphi
\end{aligned}
$$

It can be seen that the instantaneous mechanical efficiency of the engine in the compressor system is the square angle of the beta sinus (2):

$$
\left\{\begin{array}{l}
\eta_{i}^{c}=\frac{P_{u}}{P_{c}}=\frac{F_{m} \cdot l_{1} \cdot \omega \cdot \sin ^{2}(\psi-\varphi)}{F_{m} \cdot l_{1} \cdot \omega} \\
=\sin ^{2}(\psi-\varphi) ; \beta=\psi-\varphi \\
\eta_{i}^{c}=\sin ^{2}(\psi-\varphi)=\sin ^{2} \beta
\end{array}\right.
$$

The beta angle is the difference between the angle of cone positioning and the crank handle.

Now we can calculate the mechanical efficiency of the motor mechanism in a schematic by the compressor by integrating the instantaneous efficiency (link system 3 ):

$$
\begin{aligned}
& \left\{\eta_{i}^{c}=\frac{P_{u}}{P_{c}}=\frac{F_{m} \cdot l_{1} \cdot \omega \cdot \sin ^{2}(\psi-\varphi)}{F_{m} \cdot l_{1} \cdot \omega}\right. \\
& =\sin ^{2}(\psi-\varphi) ; \quad \beta=\psi-\varphi ; \\
& \text { with } \beta_{M}=\pi ; \beta_{m}=0 \Rightarrow \\
& \eta^{c}=\frac{1}{\Delta \beta} \cdot \int_{\beta_{m}}^{\beta_{M}} \sin ^{2} \beta d \beta \\
& =\frac{1}{\Delta \beta} \cdot \int_{\beta_{m}}^{\beta_{M}} \frac{1-\cos 2 \beta}{2} d \beta \\
& \left\{=\frac{1}{2 \cdot \Delta \beta} \cdot \int_{\beta_{m}}^{\beta_{M}}(1-\cos 2 \beta) d \beta\right. \\
& =\frac{1}{2 \cdot \Delta \beta} \cdot\left[\beta-\frac{\sin 2 \beta}{2}\right]_{\beta_{m}}^{\beta_{M}} \\
& =\frac{\Delta \beta}{2 \cdot \Delta \beta}-\frac{1}{4 \cdot \Delta \beta} \cdot\left(\sin 2 \beta_{M}-\sin 2 \beta_{m}\right) \\
& =\frac{1}{2}-0=\frac{1}{2} \\
& \eta^{c}=\frac{1}{2}=0.5=50 \%
\end{aligned}
$$

If the friction losses are neglected, the mechanical efficiency of the Otto engine in the compressor scheme can be considered equal to 0.5 .

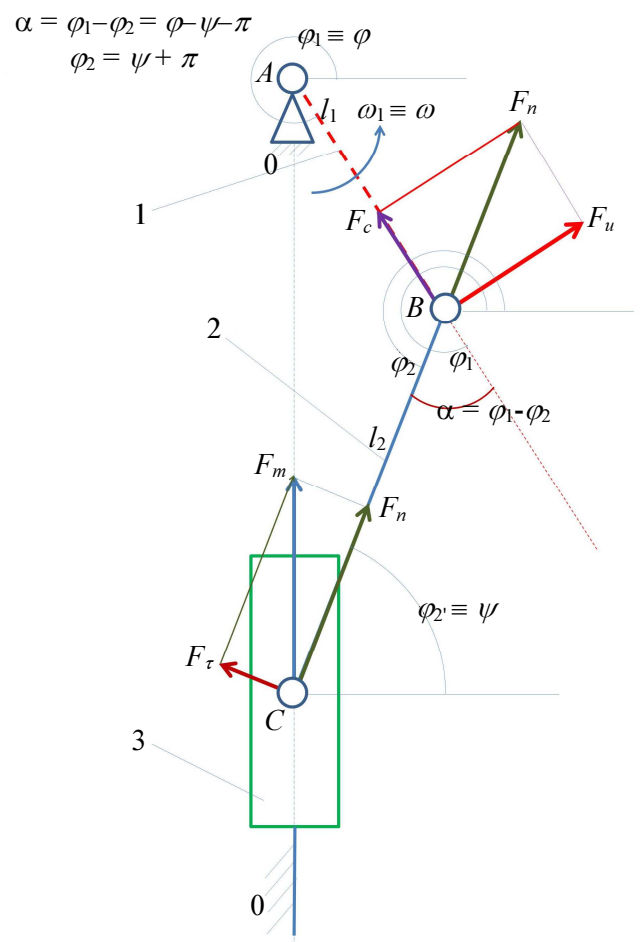

Fig. 2: The forces distribution in engine mechanism, when it is operated of the piston (element 3 ) 


\section{Presents the Algorithm for the Otto Engine in Motor System}

Now, we shall see the engine main mechanism in the motor system (when the motor mechanism is acting from the piston; see the Fig. 2).

In this case, the useful power is a real one, being produced by the motor piston (element 3 ).

It is to be noted that motive power on now from the piston is divided in two components, normal and tangential, only normal component being transmitted through con rod to the coupler B, where shall also be divided into two other components, $F_{u}$ and $F_{c}$, of which only useful component is turning the handle, while component of compression presses on the crankpin (B) and then on the crank and bearing (A).

We can write the following relations of calculation (4):

$$
\begin{aligned}
& \left\{\begin{array}{l}
F_{\tau}=F_{m} \cdot \cos \psi \\
F_{n}=F_{m} \cdot \sin \psi
\end{array} ;\right. \\
& \sin \left(\varphi_{1}-\varphi_{2}\right)=\sin (\varphi-\psi-\pi) \\
& =\sin (\psi-\varphi) \\
& F_{c}=F_{n} \cdot \cos \left(\varphi-\varphi_{2}\right) \\
& \left\{F_{u}=F_{n} \cdot \sin \left(\varphi-\varphi_{2}\right)\right. \\
& =F_{m} \cdot \sin \psi \cdot \sin (\psi-\varphi) \\
& y_{C}=l_{1} \cdot \sin \varphi-l_{2} \cdot \sin \psi \\
& v_{C} \equiv \dot{y}_{C}=l_{1} \cdot \cos \varphi \cdot \dot{\varphi}-l_{2} \cdot \cos \psi \cdot \dot{\psi} \\
& =l_{1} \cdot \cos \varphi \cdot \dot{\varphi}-l_{2} \cdot \cos \psi \cdot \lambda \cdot \frac{\sin \varphi}{\sin \psi} \cdot \dot{\varphi} \\
& =\frac{l_{1} \cdot \dot{\varphi}}{\sin \psi} \cdot(\sin \psi \cdot \cos \varphi-\sin \varphi \cdot \cos \psi) \\
& =\frac{l_{1} \cdot \sin (\psi-\varphi) \cdot \omega}{\sin \psi} \\
& P_{u}=F_{u} \cdot v_{u}=F_{m} \cdot \sin \psi \cdot \sin (\psi-\varphi) \cdot l_{1} \cdot \omega \\
& \left\{P_{c}=F_{m} \cdot v_{c}=F_{m} \cdot l_{1} \cdot \omega \cdot \frac{\sin (\psi-\varphi)}{\sin \psi}\right. \\
& \eta_{i}^{m}=\frac{P_{u}}{P_{c}} \\
& \begin{array}{l}
=\frac{F_{m} \cdot \sin \psi \cdot \sin (\psi-\varphi) \cdot l_{1} \cdot \omega}{F_{m} \cdot l_{1} \cdot \omega \cdot \frac{\sin (\psi-\varphi)}{\sin \psi}} ; \\
\eta_{i}^{m}=\sin ^{2} \psi
\end{array}
\end{aligned}
$$

It can be seen that instantly mechanical efficiency of the engine in the motor system is sinus square angle $\psi(5)$ :

$$
\eta_{i}^{m}=\sin ^{2} \psi
$$

The instantly efficiency of the engine in motor system depends only on the position angle of the con rod.
It can be calculated now approximately the mechanical efficiency of engine mechanism in scheme by the motor, through the integration of instantly yield (relations system 6):

$$
\left\{\begin{array}{l}
\eta^{m}=\frac{1}{\Delta \psi} \cdot \int_{\psi_{m}}^{\psi_{M}} \sin ^{2} \psi d \psi \\
=\frac{1}{\Delta \psi} \cdot \int_{\psi_{m}}^{\psi_{M}} \frac{1-\cos 2 \psi}{2} d \psi \\
=\frac{1}{2 \cdot \Delta \psi} \cdot \int_{\psi_{m}}^{\psi_{M}}(1-\cos 2 \psi) d \psi \\
=\frac{1}{2 \cdot \Delta \psi} \cdot\left[\psi-\frac{\sin 2 \psi}{2}\right]_{\psi_{m}}^{\psi_{M}} \\
=\frac{\Delta \psi}{2 \cdot \Delta \psi}-\frac{1}{4 \cdot \Delta \psi} \cdot\left(\sin 2 \psi_{M}-\sin 2 \psi_{m}\right) \\
=\frac{1}{2}-\frac{1}{4 \cdot \Delta \psi} \cdot\left(\sin 2 \psi_{M}-\sin 2 \psi_{m}\right) \\
=\left\{\begin{array}{l}
\Delta \psi=\psi_{M}-\psi_{m}=\pi-2 \cdot \psi_{m} ; \\
\psi_{M}=\pi-\psi_{m} ; \\
\sin \left(2 \psi_{M}\right)=\sin \left(2 \pi-2 \psi_{m}\right)=-\sin 2 \psi_{m} \\
\cos \psi=\lambda \cdot \cos \varphi ; \psi=\arccos (\lambda \cdot \cos \phi) \\
\psi_{m}=\frac{\pi}{2}-\arcsin \lambda ; \cos \psi_{m}=\lambda ; \\
\sin \psi_{m}=\sqrt{1-\lambda^{2}} \\
\eta^{m}=\frac{1}{2}-\frac{-2 \cdot \sin 2 \psi_{m}}{4 \cdot \Delta \psi} \\
=\frac{1}{2}+\frac{\sin 2 \psi_{m}}{2 \cdot\left(\pi-2 \cdot \psi_{m}\right)} \\
\eta^{m}=\frac{1}{2}+\frac{\lambda \cdot \sqrt{1-\psi_{m}}}{2 \cdot \arcsin \lambda} \cdot \cos \psi_{m} \\
2 \cdot 2 \cdot \psi_{m}
\end{array}\right.
\end{array}\right.
$$

Only are retained relations (7) in the calculation of mechanical efficiency for the two situations of the mechanism Otto cycle engine, when mechanism working in arrangements by the compressor and then when mechanism working in arrangements by the motor:

$\left\{\begin{array}{l}\eta^{c}=\frac{1}{2} \\ \eta^{m}=\frac{1}{2}+\frac{\lambda \cdot \sqrt{1-\lambda^{2}}}{2 \cdot \arcsin \lambda}\end{array}\right.$

\section{Results}

The yield heat shield (to be used as a general rule the one given by Carnot cycle) is a function of the average temperature of the engine (see diagram in Fig. 3). 


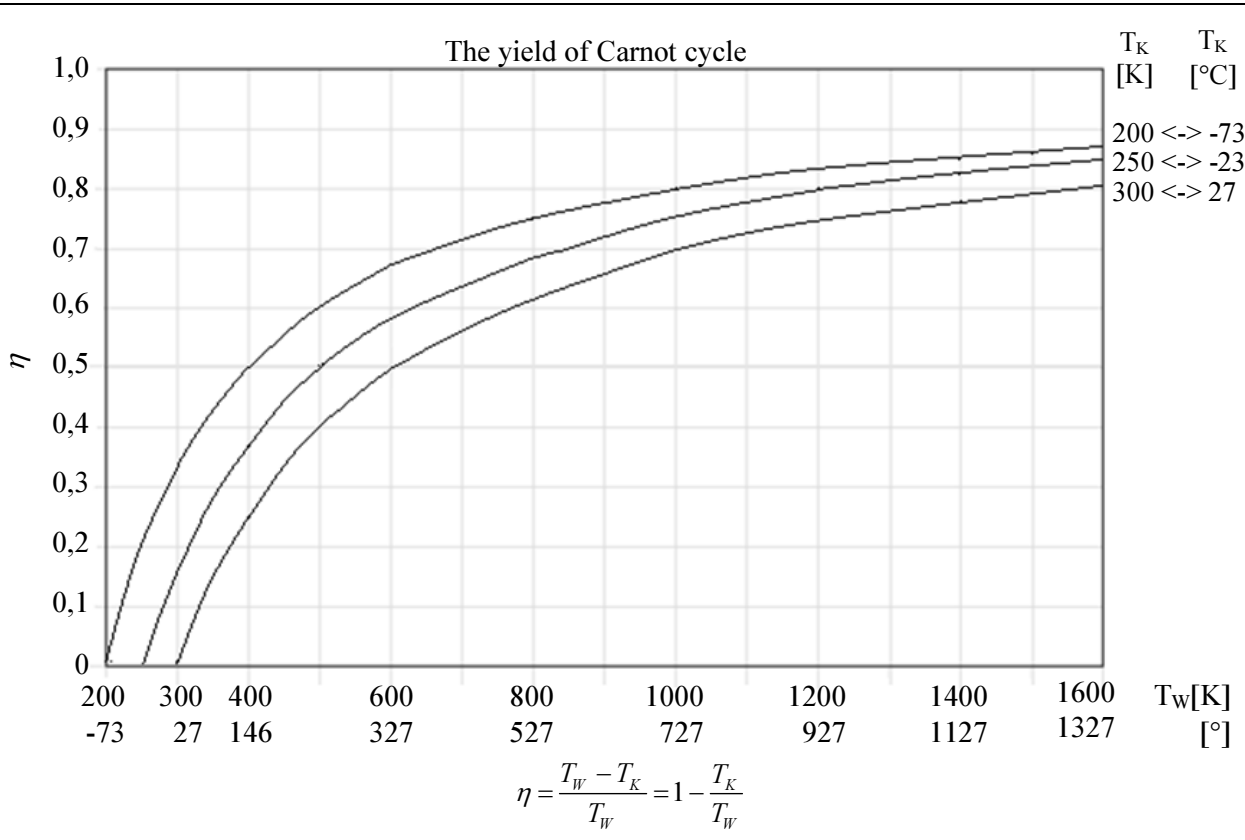

Fig. 3: The heat yield of Carnot cycle

For a minimum temperature (cooling) equal to that of the external air and a maximum working temperature of the engine of about $1,000(\mathrm{~K})$ it obtains a yield motor heat judged good, of 0.7 i.e. $70 \%$.

Consider below this value of thermal efficiency which may be obtained for thermal engines internal combustion, but it's difficult and especially to keep those with external combustion, will be determined the values of final yield of an internal combustion engine for three individual cases: A two-stroke engine (Lenoir), a fourstroke engine (Otto or diesel) normally and one fourstroke in $\mathrm{V}$ (see the relationship 8).

$$
\begin{aligned}
& \eta^{c}=\frac{1}{2} ; \eta^{m}=\frac{1}{2}+\frac{\lambda \cdot \sqrt{1-\lambda^{2}}}{2 \cdot \arcsin \lambda} \\
& \eta^{\text {mot.in.two.stroke }}=\eta^{t} \cdot \eta^{\text {mec }} ; \text { with } \\
& \text { with } \eta^{\text {mec }}=\frac{\eta^{c}+\eta^{m}}{2} \\
& =\frac{1}{2} \cdot\left(\frac{1}{2}+\frac{1}{2}+\frac{\lambda \cdot \sqrt{1-\lambda^{2}}}{2 \cdot \arcsin \lambda}\right)=\frac{1}{2}+\frac{\lambda \cdot \sqrt{1-\lambda^{2}}}{4 \cdot \arcsin \lambda} \\
& \eta^{\text {mot.in. four. stroke.normal }}=\eta^{t} \cdot \eta^{\text {mec }} ; \text { with } \\
& \text { with } \eta^{m e c}=\frac{3 \cdot \eta^{c}+\eta^{m}}{4} \\
& =\frac{1}{4} \cdot\left(\frac{3}{2}+\frac{1}{2}+\frac{\lambda \cdot \sqrt{1-\lambda^{2}}}{2 \cdot \arcsin \lambda}\right)=\frac{1}{2}+\frac{\lambda \cdot \sqrt{1-\lambda^{2}}}{8 \cdot \arcsin \lambda} \\
& \eta^{\text {mot. in. four.stroke.in.V }}=\eta^{t} \cdot \eta^{\text {mec }} ; \text { with } \\
& \text { with } \eta^{\text {mec }}=\frac{3 \cdot \eta^{c}+2 \cdot \eta^{m}}{4} \\
& =\frac{1}{4} \cdot\left(\frac{3}{2}+\frac{2}{2}+\frac{2 \lambda \cdot \sqrt{1-\lambda^{2}}}{2 \cdot \arcsin \lambda}\right)=\frac{5}{8}+\frac{\lambda \cdot \sqrt{1-\lambda^{2}}}{4 \cdot \arcsin \lambda}
\end{aligned}
$$

\section{Discussion}

The paper presents a personal view of engineering design for machine building. More thermal engines are considered. History, classification and uses are briefly dealt with. Some types of internal combustion engines are presented in more detail because they have marked our existence for the last 150 years.

Of greater importance are the Otto or Diesel internal combustion engines, the two-stroke, rotary motors and external combustion thermal engines, especially the Watt steam engines, or the Stirling which operates on the basis of the temperature difference between two sources.

The development and diversification of road vehicles and vehicles, especially cars, together with thermal engines, especially internal combustion engines (being more compact, robust, more independent, more reliable, stronger, more dynamic etc.) has also forced the development of devices, mechanisms and component assemblies at a faster pace. The most studied are the power and transmission trains.

The problem of very low yields, high emissions and very high power and fuel consumption has been greatly improved and regulated over the past 20 to 30 years by developing and introducing modern engine and distribution mechanisms that, besides higher yields (which immediately bring a high fuel economy) also performs optimal noise-free, vibration-free, no-smokefree operation, as the maximum possible engine speed has increased from 5000-6000 to about 30000 [rpm].

Particular performance is the further increase in the mechanical efficiency of the main engine and distribution system to untapped quotas so far, which will bring a major fuel economy. 
Today all internal combustion engines (but also those with external combustion which are still in use) generally operate at high, low fuel consumption levels with low vibration and noise levels with extremely low emissions, according to current regulations who are also increasingly demanding.

The current oil and energy reserves of mankind are limited. Until the implementation of new energy sources (to take real control over fossil fuels), a real alternative source of energy and fuel is even "the reduction in fuel consumption of a vehicle", whether we burn oil, gas and petroleum derivatives, whether we will implement biofuels first (something that has been done in some countries, such as Brazil, USA, Germany, etc.) and later hydrogen (extracted from water).

The drop in fuel consumption for a given type of vehicle for a hundred kilometers traveled has been consistent since 1980 and has continued to continue in the future.

Even if hybrids and electric motor cars are to be multiplied, let's not forget that they have to be charged with electricity, which is generally obtained by burning fossil fuels, especially oil and gas, in a current planetary proportion of about $60 \%$. We burn oil in large heat plants to heat ourselves, have domestic hot water and electricity for domestic, street, industrial, commercial, etc. and some of that energy is extra and we add it to the (auto) with electric motors, but the global energy problem is not solving, the crisis is even deepening. This was the case when we electrified the railroad for trains, when we generalized trams, trolleybuses and metro uses, consuming more electric power mainly from oil; oil consumption rose sharply and its price had a huge leap.

The worst aspect of this (which seems to have gone unnoticed by the great governments of the contemporary world) is that pollution and consumption due to additional oil, oil and gas bursts in global power plants have increased very much and very suddenly, due to the increased consumption of electricity, largely obtained from the burning of the extinct classical fuels (the Earth's oil reserves may actually be exhausted in the next 40-50 years if we continue to do so because the newly implemented energies, renewable and sustainable only if they account for $2-3 \%$ insignificant in global energy production, with about $40 \%$ being made from new biofuels, from biomass, from fossil and hydropower. For the time being, wind, solar, tidal, ocean, geyser, chemical or other sources now barely reach about $1-3 \%$ of global energy production (including the electrical one).

What's really going on? We are always hearing about the efforts that the world's major governments are making for the forced implementation of such new, clean and sustainable technologies, especially new solar and wind power plants. Announced increases are about 30$40 \%$ annually and yet their yield, their presence in the share of world energy obtained remains insignificant.
The fact is that these increases are also related to such globally existing technologies, which are still insignificant overall and a $40 \%$ increase of $1-2 \%$ represents a real increase of about $0.8 \%$ annually, which is barely observes the conditions of preserving global energy production and consumption because, unfortunately, both global energy consumption and global energy production suffer a yearly significant percentage increase that not only equates but sometimes exceeds the actual growth rate of modern renewables, solar power, etc.), so that much more sustained growth would be needed for clean new energies, in order to achieve a gradual real replacement of petroleum, petroleum, natural gas and coal plants.

Generally generalizing electric cars (though we are not really ready for this), we will give a new blow to oil and gas reserves.

Fortunately, biofuels, biomass and nuclear power have developed very much lately (currently based on the nuclear fission reaction). These together with the hydropower plants have managed to produce about $40 \%$ of the real global energy consumed. Only about $2-3 \%$ of global energy resources are produced by various other alternative methods (despite the efforts made so far).

This should not disarm us and abandon the implementation of solar, wind, etc.

However, as a first need to further reduce the share of global energy from oil and gas, the first vigorous measures that will need to be pursued will be to increase biomass and biofuels production, along with the expansion of nuclear power plants (despite some undesirable events that only show that nuclear fission power plants have to be built with a high degree of safety and in no way eliminated from now on, still being the one that has been so far "a bad evil ").

Alternative sources will take them on an unprecedented scale, but we expect the energy they provide to be more consistent in global percentages so we can rely on them in real terms (otherwise, we risk that all these alternative energies remain a sort of "fairy tale").

Hydrogen fuel-energy programs, "when they start, when they stop" so there's no real time now to save energy through them, so they can no longer be a top priority, but the trucks and buses could even be implemented now that the storage problems have been partially solved. The biggest problem with hydrogen is no longer the safe storage, but a large amount of energy required for extracting it and especially for its bottling. The huge amount of electricity consumed for bottling hydrogen will have to be totally obtained through alternative energy sources, otherwise, hydrogen programs will not be profitable for humanity at least for the time being. Personally, the immediate use of hydrogen extracted from water with alternative energies would be more appropriate for sea, buses and lorries. 
As long as renewables do not represent at least 80$90 \%$ of the world's energy production, there is no point in replacing thermal engines on electric cars.

When the use of supplies (oil, petroleum products, gas, coal) will account for only $10-15 \%$ of the energy produced globally every year, then we will be able to consider the implementation of electric motor cars rather than those with thermal motors.

So, for the time being, it is not beneficial to replace the car park equipped with thermal motors, with an electrified one and not only not beneficial, but it is not really possible either.

Maybe just to say that due to the classic (with thermal engines) car in full energy crisis (and not just energy, from 1970 until today), the production of cars and cars has increased at an alert pace (but naturally) instead of to decrease and they have also been marketed and used. At the start of the global energy crisis (in the 1970s) from around 200 million vehicles worldwide, the figure of about 350 million was reached in 1980 (when the energy crisis and world fuel was declared for the first time), about 500 million vehicles worldwide and in 1997 the number of world-registered vehicles exceeded 600 million. In 2010, over 800 million vehicles circulate across the planet. Soon, the number of road vehicles in circulation, which increased fourfold during the 1970s and to the 2010 crisis, ranged from 200 million to 800 million and reached the billion after the year 2010. Who can quickly house a car fleet of a billion cars to replace it entirely with an electrified one? What is the money, when the increased efforts of the governments of all countries are barely able to withdraw annually about 1$2 \%$ of the fleet of cars that are in excess of 20-30 years since they are in circulation?

\section{Conclusion}

Recently the oil reserves of the planet have multiplied by the discovery of new oil fields and with the green or nuclear energy programs already massively implemented and with public electric transport, oil has been greatly saved, so that if in 1970-1980 when the energy crisis and especially the fossil fuels began to predict a rapid exhaustion of all fossil fuels, today we have real reserves of oil for another 100-200 years under the conditions of their rational use.

But more than that, it has been discovered and already started to use shale gas (deep-sea), which has increased the reserve of already existent gas to about 2000 years for Terra.

Some say it will be sad to drive cars only with gas, but they have already grown so much and so are heavy passenger airplanes. In addition, the future sounds good for Otto and even Diesel, because today there are technological processes to turn the gas into any desired type of fuel, gasoline, diesel ...
There have already been installed worldwide three major conversion plants, can process huge amounts of gas by turning it into any kind of classic fuel, gasoline, diesel ... Such plants will multiply quickly and then gas reserves for another two thousand years will actually mean a gas reserve and diesel for another two thousand years for the planet.

Under these conditions, the electric engine will have to come in a package with many real improvements to replace Otoo and Diesel on future cars.

So we can say that the struggle between them continues and will be even sorer in the future.

As long as the magnetic engine has no reliability, it demagnetized quickly and the water engines are not yet ready to start at the industrial scale, the only real enemy of the Otto engines and diesel is the hydrogen systems that will either burn the stored hydrogen at high pressure in honey cells, whether they will burn hydrogen extracted directly from water by convenient energy methods, using nanotechnologies, pressure, precious metal catalysts and ultraviolet radiation, once developed will not favor fuel engines, because hydrogen burning is more convenient in special burners than in thermal engines, which will eventually lead to the use of electric motors in the vehicle, even if the main source of energy will be the hydrogen.

The old classic engines yield can be improved by using a two-stroke engine or a four-stroke in $\mathrm{V}$ engine.

To the four-stroke engines, the efficiency can be improved by increasing the efficiency of the distribution mechanism and the thermal yield, by increasing the temperature of work and or decreasing the cooling temperature.

\section{Acknowledgement}

This text was acknowledged and appreciated by Dr. Veturia CHIROIU Honorific member of Technical Sciences Academy of Romania (ASTR) PhD supervisor in Mechanical Engineering.

\section{Funding Information}

Research contract: 1-Research contract: Contract number 36-5-4D/1986 from 24IV1985, beneficiary CNST RO (Romanian National Center for Science and Technology) Improving dynamic mechanisms.

2-Contract research integration. 19-91-3 from 29.03.1991; Beneficiary: MIS; TOPIC: Research on designing mechanisms with bars, cams and gears, with application in industrial robots.

3-Contract research. GR 69/10.05.2007: NURC in 2762; theme 8: Dynamic analysis of mechanisms and manipulators with bars and gears.

4-Labor contract, no. 35/22.01.2013, the UPB, "Stand for reading performance parameters of kinematics and 
dynamic mechanisms, using inductive and incremental encoders, to a Mitsubishi Mechatronic System" "PN-IIIN-CI-2012-1-0389".

All these matters are copyrighted! Copyrights: 394qodGnhhtej, from 17-02-2010 13:42:18; 463vpstuCGsiy, from 20-03-2010 12:45:30; 631sqfsgquutm, from 24-05-2010 16:15:22; 933CrDztEfqow, from 07-01-2011 13:37:52.

\section{Author's Contributions}

All the authors contributed equally to prepare, develop and carry out this manuscript.

\section{Ethics}

This article is original and contains unpublished material. Authors declare that are not ethical issues and no conflict of interest that may arise after the publication of this manuscript.

\section{References}

Ab-Rahman, M.S., H. Guna, MH. Harun, SD. Zan and K. Jumari, 2009. Cost-effective fabrication of selfmade $1 \times 12$ polymer optical fiber-based optical splitters for automotive application. Am. J. Eng. Applied Sci., 2: 252-259. DOI: 10.3844/ajeassp.2009.252.259

Abam, F.I., I.U. Ugot and D.I. Igbong, 2012. Performance analysis and components irreversibilities of a $(25 \mathrm{MW})$ gas turbine power plant modeled with a spray cooler. Am. J. Eng. Applied Sci., 5: 35-41.

DOI: 10.3844/ajeassp.2012.35.41

Abdelkrim, H., S.B. Othman, A.K.B. Salem and S.B. Saoud, 2012. Dynamic partial reconfiguration contribution on system on programmable chip architecture for motor drive implementation. Am. J. Eng. Applied Sci., 5: 15-24. DOI: 10.3844/ajeassp.2012.15.24

Abdullah, M.Z., A. Saat and Z. Hamzah, 2011. Optimization of energy dispersive x-ray fluorescence spectrometer to analyze heavy metals in moss samples. Am. J. Eng. Applied Sci., 4: 355-362. DOI: 10.3844 /ajeassp.2011.355.362

Abdullah, M., A. F.M. Zain, Y. H. Ho and S. Abdullah, 2009. TEC and scintillation study of equatorial ionosphere: A month campaign over sipitang and parit raja stations, Malaysia. Am. J. Eng. Applied Sci., 2: 44-49. DOI: 10.3844/ajeassp.2009.44.49

Abdullah, H. and S.A. Halim, 2009. Electrical and magnetoresistive studies $\mathrm{Nd}$ doped on La-Ba-Mn-O manganites for low-field sensor application. Am. J. Eng. Applied Sci., 2: 297-303.

DOI: 10.3844/ajeassp.2009.297.303
Abouobaida, H., 2016. Robust and efficient controller to design a standalone source supplied DC and AC load powered by photovoltaic generator. Am. J. Eng. Applied Sci., 9: 894-901.

DOI: 10.3844 /ajeassp.2016.894.901

Abu-Ein, S., 2009. Numerical and analytical study of exhaust gases flow in porous media with applications to diesel particulate filters. Am. J. Eng. Applied Sci., 2: 70-75. DOI: 10.3844/ajeassp.2009.70.75

Abu-Lebdeh, M., G. Pérez-de León, S.A. Hamoush, R.D. Seals and V.E. Lamberti, 2016. Gas atomization of molten metal: Part II. Applications. Am. J. Eng. Applied Sci., 9: 334-349. DOI: 10.3844 /ajeassp.2016.334.349

Agarwala, S., 2016. A perspective on 3D bioprinting technology: Present and future. Am. J. Eng. Applied Sci., 9: 985-990.

DOI: 10.3844/ajeassp.2016.985.990

Ahmed, M., R. Khan, M. Billah and S. Farhana, 2010. A novel navigation algorithm for hexagonal hexapod robot. Am. J. Eng. Applied Sci., 3: 320-327. DOI: 10.3844 /ajeassp.2010.320.327

Ahmed, M.K., H. Haque and H. Rahman, 2016. An approach to develop a dynamic job shop scheduling by fuzzy rule-based system and comparative study with the traditional priority rules. Am. J. Eng. Applied Sci., 9: 202-212.

DOI: 10.3844/ajeassp.2016.202.212

Akhesmeh, S., N. Pourmahmoud and H. Sedgi, 2008. Numerical study of the temperature separation in the ranque-hilsch vortex tube. Am. J. Eng. Applied Sci., 1: 181-187. DOI: 10.3844/ajeassp.2008.181.187

Al-Abbas, I.K., 2009. Reduced order models of a current source inverter induction motor drive. Am. J. Eng. Applied Sci., 2: 39-43.

DOI: 10.3844/ajeassp.2009.39.43

Al-Hasan and A.S. Al-Ghamdi, 2016. Energy balance for a diesel engine operates on a pure biodiesel, diesel fuel and biodiesel-diesel blends. Am. J. Eng. Applied Sci., 9: 458-465. DOI: 10.3844 /ajeassp.2016.458.465

Al Smadi, T.A., 2011. Low cost smart sensor design. Am. J. Eng. Applied Sci., 4: 162-168. DOI: 10.3844/ajeassp.2011.162.168

Al Qadi, A.N.S., M.B.A. ALhasanat, A. AL Dahamsheh and S. AL Zaiydneen, 2016a. Using of box-benken method to predict the compressive strength of selfcompacting concrete containing Wadi Musa bentonite, Jordan. Am. J. Eng. Applied Sci., 9: 406-411. DOI: 10.3844/ajeassp.2016.406.411

Al Qadi, A.N.S., M.B.A. Alhasanat and M. Haddad, 2016b. Effect of crumb rubber as coarse and fine aggregates on the properties of asphalt concrete. Am. J. Eng. Applied Sci., 9: 558-564. DOI: 10.3844/ajeassp.2016.558.564 
Aleksic, S. and A. Lovric, 2011. Energy consumption and environmental implications of wired access networks. Am. J. Eng. Applied Sci., 4: 531-539. DOI: 10.3844/ajeassp.2011.531.539

Alhasanat, M.B., A.N. Al Qadi, O.A. Al Khashman and A. Dahamsheh, 2016. Scanning electron microscopic evaluation of self-compacting concrete spalling at elevated temperatures. Am. J. Eng. Applied Sci., 9: 119-127.

DOI: $10.3844 /$ ajeassp.2016.119.127

Ali, K.S. and J.L. Shumaker, 2013. Hardware in the loop simulator for multi-agent unmanned aerial vehicles environment. Am. J. Eng. Applied Sci., 6: 172-177. DOI: 10.3844/ajeassp.2013.172.177

Ali, G.A.M., O. Fouad and S.A. Makhlouf, 2016. Electrical properties of cobalt oxide/silica nanocomposites obtained by sol-gel technique. Am. J. Eng. Applied Sci., 9: 12-16.

DOI: 10.3844 /ajeassp.2016.12.16

Al-Nasra, M. Daoudb and T.M. Abu-Lebdeh, 2015. The use of the super absorbent polymer as water blocker in concrete structures. Am. J. Eng. Applied Sci., 8: 659-665. DOI: 10.3844/ajeassp.2015.659.665

Alwetaishi, M.S., 2016. Impact of building function on thermal comfort: A review paper. Am. J. Eng. Applied Sci., 9: 928-945.

DOI: 10.3844/ajeassp.2016.928.945

Aly, W.M. and M.S. Abuelnasr, 2010. Electronic design automation using object oriented electronics. Am. J. Eng. Applied Sci., 3: 121-127.

DOI: $10.3844 /$ ajeassp.2010.121.127

Amani, N., 2016. Design and implementation of optimum management system using cost evaluation and financial analysis for prevention of building failure. Am. J. Eng. Applied Sci., 9: 281-296. DOI: 10.3844/ajeassp.2016.281.296

Amer, S., S. Hamoush and T.M. Abu-Lebdeh, 2015. Experimental evaluation of the raking energy in damping system of steel stud partition walls. Am. J. Eng. Applied Sci., 8: 666-677.

DOI: 10.3844/ajeassp.2015.666.677

Anizan, S., K. Yusri, C.S. Leong, N. Amin and S. Zaidi et al., 2011. Effects of the contact resistivity variations of the screen-printed silicon solar cell. Am. J. Eng. Applied Sci., 4: 328-331. DOI: 10.3844/ajeassp.2011.328.331

Antonescu, P. and F. Petrescu, 1985. An analytical method of synthesis of cam mechanism and flat stick. Proceedings of the 4th International Symposium on Theory and Practice of Mechanisms, (TPM' 89), Bucharest.

Antonescu, P. and F. Petrescu, 1989. Contributions to kinetoplast dynamic analysis of distribution mechanisms. Bucharest.
Antonescu, P., M. Oprean and F. Petrescu, 1985a. Contributions to the synthesis of oscillating cam mechanism and oscillating flat stick. Proceedings of the 4th International Symposium on Theory and Practice of Mechanisms, (TPM' 85), Bucharest.

Antonescu, P., M. Oprean and F. Petrescu, 1985b. At the projection of the oscillate cams, there are mechanisms and distribution variables. Proceedings of the 5th Conference of Engines, Automobiles, Tractors and Agricultural Machines, (TAM' 58), IMotors and Cars, Brasov.

Antonescu, P., M. Oprean and F. Petrescu, 1986. Projection of the profile of the rotating camshaft acting on the oscillating plate with disengagement. Proceedings of the 3rd National Computer-aided Design Symposium in the field of Mechanisms and Machine Parts, (MMP' 86), Brasov.

Antonescu, P., M. Oprean and F. Petrescu, 1987. Dynamic analysis of the cam distribution mechanisms. Proceedings of the 7th National Symposium on Industrial Robots and Space Mechanisms, (RSM' 87), Bucharest.

Antonescu, P., M. Oprean and F. Petrescu, 1988. Analytical synthesis of Kurz profile, rotating the flat cam. Mach, Build. Rev.

Antonescu, P., F. Petrescu and O. Antonescu, 1994. Contributions to the synthesis of the rotating cam mechanism and the tip of the balancing tip. Brasov.

Antonescu, P., F. Petrescu and D. Antonescu, 1997. Geometrical synthesis of the rotary cam and balance tappet mechanism. Bucharest, 3: 23-23.

Antonescu, P., F. Petrescu and O. Antonescu, 2000a. Contributions to the synthesis of the rotary disc-cam profile. Proceedings of the 8th International Conference on the Theory of Machines and Mechanisms, (TMM' 00), Liberec, Czech Republic, pp: 51-56.

Antonescu, P., F. Petrescu and O. Antonescu, 2000b. Synthesis of the rotary cam profile with balance follower. Proceedings of the 8th Symposium on Mechanisms and Mechanical Transmissions, (MMT' 00), Timişoara, pp: 39-44.

Antonescu, P., F. Petrescu and O. Antonescu, 2001. Contributions to the synthesis of mechanisms with rotary disc-cam. Proceedings of the 8th IFToMM International Symposium on Theory of Machines and Mechanisms, (TMM' 01), Bucharest, ROMANIA, pp: 31-36.

Ascione, F., N. Bianco, R.F. De Masi, F. de Rossi and C. De Stasio et al., 2016. Energy audit of health care facilities: dynamic simulation of energy performances and energy-oriented refurbishment of system and equipment for microclimatic control. Am. J. Eng. Applied Sci., 9: 814-834. DOI: 10.3844/ajeassp.2016.814.834 
Augustine, A., R.D. Prakash, R. Xavier and M.C. Parassery, 2016. Review of signal processing techniques for detection of power quality events. Am. J. Eng. Applied Sci., 9: 364-370.

DOI: 10.3844 /ajeassp.2016.364.370

Aversa, R., R.V.V. Petrescu, A. Apicella and F.I.T. Petrescu, 2017a. Nano-diamond hybrid materials for structural biomedical application. Am. J. Biochem. Biotechnol., 13: 34-41. DOI: 10.3844 /ajbbsp.2017.34.41

Aversa, R., R.V. Petrescu, B. Akash, R.B. Bucinell and J.M. Corchado et al., 2017b. Kinematics and forces to a new model forging manipulator. Am. J. Applied Sci., 14: 60-80. DOI: $10.3844 /$ ajassp.2017.60.80

Aversa, R., R.V. Petrescu, A. Apicella, F.I.T. Petrescu and J.K. Calautit et al., 2017c. Something about the $\mathrm{V}$ engines design. Am. J. Applied Sci., 14: 34-52. DOI: 10.3844/ajassp.2017.34.52

Aversa, R., D. Parcesepe, R.V.V. Petrescu, F. Berto and G. Chen et al., 2017d. Process ability of bulk metallic glasses. Am. J. Applied Sci., 14: 294-301. DOI: 10.3844/ajassp.2017.294.301

Aversa, R., R.V.V. Petrescu, B. Akash, R.B. Bucinell and J.M. Corchado et al., 2017e. Something about the balancing of thermal motors. Am. J. Eng. Applied Sci., 10: 200.217. DOI: 10.3844/ajeassp.2017.200.217

Aversa, R., F.I.T. Petrescu, R.V. Petrescu and A. Apicella, 2016a. Biomimetic FEA bone modeling for customized hybrid biological prostheses development. Am. J. Applied Sci., 13: 1060-1067. DOI: 10.3844/ajassp.2016.1060.1067

Aversa, R., D. Parcesepe, R.V. Petrescu, G. Chen and F.I.T. Petrescu et al., 2016b. Glassy amorphous metal injection molded induced morphological defects. Am. J. Applied Sci., 13: 1476-1482.

DOI: 10.3844/ajassp.2016.1476.1482

Aversa, R., R.V. Petrescu, F.I.T. Petrescu and A. Apicella, 2016c. Smart-factory: Optimization and process control of composite centrifuged pipes. Am. J. Applied Sci., 13: 1330-1341.

DOI: 10.3844/ajassp.2016.1330.1341

Aversa, R., F. Tamburrino, R.V. Petrescu, F.I.T. Petrescu and M. Artur et al., 2016d. Biomechanically inspired shape memory effect machines driven by muscle like acting NiTi alloys. Am. J. Applied Sci., 13: 1264-1271. DOI: 10.3844/ajassp.2016.1264.1271

Aversa, R., E.M. Buzea, R.V. Petrescu, A. Apicella and M. Neacsa et al., 2016e. Present a mechatronic system having able to determine the concentration of carotenoids. Am. J. Eng. Applied Sci., 9: 1106-1111.

DOI: 10.3844/ajeassp.2016.1106.1111
Aversa, R., R.V. Petrescu, R. Sorrentino, F.I.T. Petrescu and A. Apicella, 2016f. Hybrid ceramopolymeric nanocomposite for biomimetic scaffolds design and preparation. Am. J. Eng. Applied Sci., 9: 1096-1105. DOI: 10.3844/ajeassp.2016.1096.1105

Aversa, R., V. Perrotta, R.V. Petrescu, C. Misiano and F.I.T. Petrescu et al., 2016g. From structural colors to super-hydrophobicity and achromatic transparent protective coatings: Ion plating plasma assisted $\mathrm{TiO}_{2}$ and $\mathrm{SiO}_{2}$ nano-film deposition. Am. J. Eng. Applied Sci., 9: 1037-1045.

DOI: 10.3844/ajeassp.2016.1037.1045

Aversa, R., R.V. Petrescu, F.I.T. Petrescu and A. Apicella, 2016h. Biomimetic and evolutionary design driven innovation in sustainable products development. Am. J. Eng. Applied Sci., 9: $1027-$ 1036. DOI: 10.3844 /ajeassp.2016.1027.1036

Aversa, R., R.V. Petrescu, A. Apicella and F.I.T. Petrescu, 2016i. Mitochondria are naturally micro robots - a review. Am. J. Eng. Applied Sci., 9: 991-1002. DOI: 10.3844/ajeassp.2016.991.1002

Aversa, R., R.V. Petrescu, A. Apicella and F.I.T. Petrescu, 2016j. We are addicted to vitamins $\mathrm{C}$ and E-A review. Am. J. Eng. Applied Sci., 9: 1003-1018. DOI: 10.3844/ajeassp.2016.1003.1018

Aversa, R., R.V. Petrescu, A. Apicella and F.I.T. Petrescu, 2016k. Physiologic human fluids and swelling behavior of hydrophilic biocompatible hybrid ceramo-polymeric materials. Am. J. Eng. Applied Sci., 9: 962-972.

DOI: 10.3844/ajeassp.2016.962.972

Aversa, R., R.V. Petrescu, A. Apicella and F.I.T. Petrescu, 20161. One can slow down the aging through antioxidants. Am. J. Eng. Applied Sci., 9: 1112-1126.

DOI: $10.3844 /$ ajeassp.2016.1112.1126

Aversa, R., R.V. Petrescu, A. Apicella and F.I.T. Petrescu, 2016m. About homeopathy or «Similia Similibus Curentur 》. Am. J. Eng. Applied Sci., 9: 1164-1172.

DOI: $10.3844 /$ ajeassp.2016.1164.1172

Aversa, R., R.V. Petrescu, A. Apicella and F.I.T. Petrescu, 2016n. The basic elements of life's. Am. J. Eng. Applied Sci., 9: 1189-1197. DOI: 10.3844/ajeassp.2016.1189.1197

Aversa, R., F.I.T. Petrescu, R.V. Petrescu and A. Apicella, 2016o. Flexible stem trabecular prostheses. Am. J. Eng. Applied Sci., 9: 1213-1221. DOI: 10.3844/ajeassp.2016.1213.122

Babayemi, A.K., 2016. Thermodynamics, non-linear isotherms, statistical modeling and optimization of phosphorus adsorption from wastewater. Am. J. Eng. Applied Sci., 9: 1019-1026.

DOI: 10.3844 /ajeassp.2016.1019.1026 
Bakar, R.A., M.K. Mohammed and M.M. Rahman, 2009. Numerical study on the performance characteristics of hydrogen fueled port injection internal combustion engine. Am. J. Eng. Applied Sci., 2: 407-415.

DOI: 10.3844 /ajeassp.2009.407.415

Barone, G., A. Buonomano, C. Forzano and A. Palombo, 2016. WLHP systems in commercial buildings: A case study analysis based on a dynamic simulation approach. Am. J. Eng. Applied Sci., 9: 659-668. DOI: 10.3844 /ajeassp.2016.659.668

Bedon, C., 2016. Review on the use of FRP composites for facades and building skins. Am. J. Eng. Applied Sci., 9: 713-723. DOI: 10.3844 /ajeassp.2016.713.723

Bedon, C. and C. Amadio, 2016. A unified approach for the shear buckling design of structural glass walls with non-ideal restraints. Am. J. Eng. Applied Sci., 9: 64-78. DOI: 10.3844/ajeassp.2016.64.78

Bedon, C. and C. Louter, 2016. Finite-element numerical simulation of the bending performance of posttensioned structural glass beams with adhesively bonded CFRP tendons. Am. J. Eng. Applied Sci., 9: 680-691. DOI: 10.3844/ajeassp.2016.680.691

Bier, H. and S. Mostafavi, 2015. Structural optimization for materially informed design to robotic production processes. Am. J. Eng. Applied Sci., 8: 549-555. DOI: $10.3844 /$ ajeassp.2015.549.555

Bolonkin, A., 2009a. Femtotechnology: Nuclear matter with fantastic properties. Am. J. Eng. Applied Sci., 2: 501-514. DOI: 10.3844/ajeassp.2009.501.514

Bolonkin, A., 2009b. Converting of matter to nuclear energy by ab-generator. Am. J. Eng. Applied Sci., 2: 683-693. DOI: 10.3844/ajeassp.2009.683.693

Boucetta, A., 2008. Vector control of a variable reluctance machine stator and rotor discs imbricates. Am. J. Eng. Applied Sci., 1: 260-265. DOI: 10.3844 /ajeassp.2008.260.265

Bourahla, N. and A. Blakeborough, 2015. Similitude distortion compensation for a small scale model of a knee braced steel frame. Am. J. Eng. Applied Sci., 8: 481-488. DOI: 10.3844/ajeassp.2015.481.488

Bucinell, R.B., 2016. Stochastic model for variable amplitude fatigue induced delamination growth in graphite/epoxy laminates. Am. J. Eng. Applied Sci., 9: 635-646. DOI: 10.3844/ajeassp.2016.635.646

Budak, S., Z. Xiao, B. Johnson, J. Cole and M. Drabo et al., 2016. Highly-efficient advanced thermoelectric devices from different multilayer thin films. Am. J. Eng. Applied Sci., 9: 356-363.

DOI: 10.3844/ajeassp.2016.356.363

Buonomano, A., F. Calise and M. Vicidomini, 2016a. A novel prototype of a small-scale solar power plant: Dynamic simulation and thermoeconomic analysis. Am. J. Eng. Applied Sci., 9: 770-788.

DOI: 10.3844/ajeassp.2016.770.788
Buonomano, A., F. Calise, M.D. d'Accadia, R. Vanoli and M. Vicidomini, 2016b. Simulation and experimental analysis of a demonstrative solar heating and cooling plant installed in Naples (Italy). Am. J. Eng. Applied Sci., 9: 798-813. DOI: 10.3844 /ajeassp.2016.798.813

Cao, W., H. Ding, Z. Bin and C. Ziming, 2013. New structural representation and digital-analysis platform for symmetrical parallel mechanisms. Int. J. Adv. Robotic Sys. DOI: 10.5772/56380

Calise, F., M.D. dâ' Accadia, L. Libertini, E. Quiriti and M. Vicidomini, 2016b. Dynamic simulation and optimum operation strategy of a trigeneration system serving a hospital. Am. J. Eng. Applied Sci., 9: 854-867. DOI: 10.3844/ajeassp.2016.854.867

Campo, T., M. Cotto, F. Marquez, E. Elizalde and C. Morant, 2016. Graphene synthesis by plasmaenhanced CVD growth with ethanol. Am. J. Eng. Applied Sci., 9: 574-583. DOI: 10.3844 /ajeassp.2016.574.583

Cardu, M., P. Oreste and T. Cicala, 2009. Analysis of the tunnel boring machine advancement on the Bologna-Florence railway link. Am. J. Eng. Applied Sci., 2: 416-420.

DOI: 10.3844 /ajeassp.2009.416.420

Casadei, D., 2015. Bayesian statistical inference for number counting experiments. Am. J. Eng. Applied Sci., 8: 730-735.

DOI: 10.3844 /ajeassp.2015.730.735

Calise, F., M.D. dâ' Accadia, L. Libertini, E. Quiriti and M. Vicidomini, 2016b. Dynamic simulation and optimum operation strategy of a trigeneration system serving a hospital. Am. J. Eng. Applied Sci., 9: 854-867. DOI: 10.3844/ajeassp.2016.854.867

Campo, T., M. Cotto, F. Marquez, E. Elizalde and C. Morant, 2016. Graphene synthesis by plasmaenhanced CVD growth with ethanol. Am. J. Eng. Applied Sci., 9: 574-583.

DOI: 10.3844 /ajeassp.2016.574.583

Cardu, M., P. Oreste and T. Cicala, 2009. Analysis of the tunnel boring machine advancement on the Bologna-Florence railway link. Am. J. Eng. Applied Sci., 2: 416-420.

DOI: 10.3844 /ajeassp.2009.416.420

Casadei, D., 2015. Bayesian statistical inference for number counting experiments. Am. J. Eng. Applied Sci., 8: 730-735. DOI: 10.3844 /ajeassp.2015.730.735

Comanescu, A., 2010. Bazele Modelarii Mecanismelor. 1st Edn., E. Politeh, Press, Bucureşti, pp: 274.

Darabi, A., S.A. Soleamani and A. Hassannia, 2008. Fuzzy based digital automatic voltage regulator of a synchronous generator with unbalanced loads. Am. J. Eng. Applied Sci., 1: 280-286. DOI: 10.3844 /ajeassp.2008.280.286 
Daud, H., N. Yahya, A.A. Aziz and M.F. Jusoh, 2008. Development of wireless electric concept powering electrical appliances. Am. J. Eng. Applied Sci., 1: 12-15. DOI: 10.3844/ajeassp.2008.12.15

Demetriou, D., N. Nikitas and K.D. Tsavdaridis, 2015. Semi active tuned mass dampers of buildings: A simple control option. Am. J. Eng. Applied Sci., 8: 620-632. DOI: 10.3844/ajeassp.2015.620.632

Dixit, S. and S. Pal, 2015. Synthesis and characterization of ink (Carbon)-perovskite/polyaniline ternary composite electrode for sodium chloride separation. Am. J. Eng. Applied Sci., 8: 527-537. DOI: 10.3844/ajeassp.2015.527.537

Djalel, D., M. Mourad and H. Labar, 2013. New approach of electromagnetic fields of the lightning discharge. Am. J. Eng. Applied Sci., 6: 369-383. DOI: 10.3844/ajeassp.2013.369.383

Dong, H., N. Giakoumidis, N. Figueroa and N. Mavridis, 2013. Approaching behaviour monitor and vibration indication in developing a General Moving Object Alarm System (GMOAS). Int. J. Adv. Robotic Sys. DOI: $10.5772 / 56586$

Ebrahim, N.A., S. Ahmed, S.H.A. Rashid and Z. Taha, 2012. Technology use in the virtual R\&D teams. Am. J. Eng. Applied Sci., 5: 9-14. DOI: 10.3844/ajeassp.2012.9.14

El-Labban, H.F., M. Abdelaziz and E.R.I. Mahmoud, 2013. Modification of carbon steel by laser surface melting: Part I: Effect of laser beam travelling speed on microstructural features and surface hardness. Am. J. Eng. Applied Sci., 6: 352-359. DOI: 10.3844/ajeassp.2013.352.359

Elliott, A., S. AlSalihi, A.L. Merriman and M.M. Basti, 2016. Infiltration of nanoparticles into porous binder jet printed parts. Am. J. Eng. Applied Sci., 9: 128-133. DOI: 10.3844/ajeassp.2016.128.133

Elmeddahi, Y., H. Mahmoudi, A. Issaadi, M.F.A. Goosen and R. Ragab, 2016b. Evaluating the effects of climate change and variability on water resources: A case study of the Cheliff Basin in Algeria. Am. J. Eng. Applied Sci., 9: 835-845.

DOI: 10.3844/ajeassp.2016.835.845

El-Tous, Y., 2008. Pitch angle control of variable speed wind turbine. Am. J. Eng. Applied Sci., 1: 118-120. DOI: 10.3844/ajeassp.2008.118.120

Faizal, A., S. Mulyono, R. Yendra and A. Fudholi, 2016. Design Maximum Power Point Tracking (MPPT) on photovoltaic panels using fuzzy logic method. Am. J. Eng. Applied Sci., 9: 789-797. DOI: 10.3844 /ajeassp.2016.789.797

Farahani, A.S., N.M. Adam and M.K.A. Ariffin, 2010. Simulation of airflow and aerodynamic forces acting on a rotating turbine ventilator. Am. J. Eng. Applied Sci., 3: 159-170.

DOI: $10.3844 /$ ajeassp.2010.159.170
Farokhi, E. and M. Gordini, 2015. Investigating the parameters influencing the behavior of knee braced steel structures. Am. J. Eng. Applied Sci., 8: 567-574. DOI: 10.3844/ajeassp.2015.567.574

Fathallah, A.Z.M. and R.A. Bakar, 2009. Prediction studies for the performance of a single cylinder high speed spark ignition linier engine with spring mechanism as return cycle. Am. J. Eng. Applied Sci., 2: 713-720. DOI: 10.3844 ajeassp.2009.713.720

Fen, Y.W., W.M.M. Yunus, M.M. Moksin, Z.A. Talib and N.A. Yusof, 2011. Optical properties of crosslinked chitosan thin film with glutaraldehyde using surface plasmon resonance technique. Am. J. Eng. Applied Sci., 4: 61-65. DOI: 10.3844/ajeassp.2011.61.65

Feraga, C.E., A. Moussaoui, A. Bouldjedri and A. Yousfi, 2009. Robust position controller for a permanent magnet synchronous actuator. Am. J. Eng. Applied Sci., 2: 388-392.

DOI: 10.3844 /ajeassp.2009.388.392

Franklin, D.J., 1930. Ingenious Mechanisms for Designers and Inventors. 1st Edn., Industrial Press Publisher.

Fu, Y.F., J. Gong, H. Huang, Y.J. Liu and D. Zhu et al., 2015. Parameters optimization of adaptive cashew shelling cutter based on BP neural network and genetic algorithm. Am. J. Eng. Applied Sci., 8: 648658. DOI: 10.3844/ajeassp.2015.648.658

Ge, L. and X. Xu, 2015. A scheme design of cloud + end technology in demand side management. Am. J. Eng. Applied Sci., 8: 736-747. DOI: 10.3844 /ajeassp.2015.736.747

Gupta, P., A. Gupta and A. Asati, 2015. Ultra low power MUX based compressors for wallace and dadda multipliers in sub-threshold regime. Am. J. Eng. Applied Sci., 8: 702-716. DOI: 10.3844 /ajeassp.2015.702.716

Gusti, A.P. and Semin, 2016. The effect of vessel speed on fuel consumption and exhaust gas emissions. Am. J. Eng. Applied Sci., 9: 1046-1053. DOI: 10.3844/ajeassp.2016.1046.1053

Hassan, M., H. Mahjoub and M. Obed, 2012. Voicebased control of a DC servo motor. Am. J. Eng. Applied Sci., 5: 89-92.

DOI: 10.3844 /ajeassp.2012.89.92

Hasan, S. and M.H. El-Naas, 2016. Optimization of a combined approach for the treatment of carbide slurry and capture of $\mathrm{CO}_{2}$. Am. J. Eng. Applied Sci., 9: 449-457. DOI: 10.3844/ajeassp.2016.449.457

Helmy, A.K. and G.S. El-Taweel, 2010. Neural network change detection model for satellite images using textural and spectral characteristics. Am. J. Eng. Applied Sci., 3: 604-610.

DOI: 10.3844/ajeassp.2010.604.610 
Hirun, W., 2016. Evaluation of interregional freight generation modelling methods by using nationwide commodity flow survey data. Am. J. Eng. Applied Sci., 9: 625-634.

DOI: 10.3844/ajeassp.2016.625.634

Ho, C.Y.F., B.W.K. Ling, S.G. Blasi, Z.W. Chi and W.C. Siu, 2011. Single step optimal block matched motion estimation with motion vectors having arbitrary pixel precisions. Am. J. Eng. Applied Sci., 4: 448-460. DOI: 10.3844/ajeassp.2011.448.460

Huang, B., S.H. Masood, M. Nikzad, P.R. Venugopal and A. Arivazhagan, 2016. Dynamic mechanical properties of fused deposition modelling processed polyphenylsulfone material. Am. J. Eng. Applied Sci., 9: 1-11. DOI: 10.3844/ajeassp.2016.1.11

He, B., Z. Wang, Q. Li, H. Xie and R. Shen, 2013. An analytic method for the kinematics and dynamics of a multiple-backbone continuum robot. IJARS. DOI: $10.5772 / 54051$

Idarwazeh, S., 2011. Inverse discrete Fourier transformdiscrete Fourier transform techniques for generating and receiving spectrally efficient frequency division multiplexing signals. Am. J. Eng. Applied Sci., 4: 598-606. DOI: 10.3844/ajeassp.2011.598.606

Iqbal, 2016. An overview of Energy Loss Reduction (ELR) software used in Pakistan by WAPDA for calculating transformer overloading, line losses and energy losses. Am. J. Eng. Applied Sci., 9: 442-448. DOI: 10.3844/ajeassp.2016.442.448

Ismail, M.I.S., Y. Okamoto, A. Okada and Y. Uno, 2011. Experimental investigation on micro-welding of thin stainless steel sheet by fiber laser. Am. J. Eng. Applied Sci., 4: 314-320. DOI: 10.3844/ajeassp.2011.314.320

Jaber, A.A. and R. Bicker, 2016. Industrial robot fault detection based on statistical control chart. Am. J. Eng. Applied Sci., 9: 251-263. DOI: 10.3844/ajeassp.2016.251.263

Jafari, N., A. Alsadoon, C.P. Withana, A. Beg and A. Elchouemi, 2016. Designing a comprehensive security framework for smartphones and mobile devices. Am. J. Eng. Applied Sci., 9: 724-734. DOI: 10.3844/ajeassp.2016.724.734

Jalil, M.I.A. and J. Sampe, 2013. Experimental investigation of thermoelectric generator modules with different technique of cooling system. Am. J. Eng. Applied Sci., 6: 1-7. DOI: 10.3844/ajeassp.2013.1.7

Jaoude, A.A. and K. El-Tawil, 2013. Analytic and nonlinear prognostic for vehicle suspension systems. Am. J. Eng. Applied Sci., 6: 42-56. DOI: 10.3844/ajeassp.2013.42.56

Jarahi, H., 2016. Probabilistic seismic hazard deaggregation for Karaj City (Iran). Am. J. Eng. Applied Sci., 9: 520-529.

DOI: 10.3844 /ajeassp.2016.520.529
Jarahi, H. and S. Seifilaleh, 2016. Rock fall hazard zonation in Haraz Highway. Am. J. Eng. Applied Sci., 9: 371-379.

DOI: 10.3844 /ajeassp.2016.371.379

Jauhari, K., A. Widodo and I. Haryanto, 2016. Identification of a machine tool spindle critical frequency through modal and imbalance response analysis. Am. J. Eng. Applied Sci., 9: 213-221.

DOI: 10.3844 /ajeassp.2016.213.221

Jiang, J., Q. Chen and S. Nimbalkar, 2016. Field data based method for predicting long-term settlements. Am. J. Eng. Applied Sci., 9: 466-476. DOI: 10.3844 /ajeassp.2016.466.476

Kaewnai, S. and S. Wongwises, 2011. Improvement of the runner design of Francis turbine using computational fluid dynamics. Am. J. Eng. Applied Sci., 4: 540-547. DOI: 10.3844 /ajeassp.2011.540.547

Khalifa, A.H.N., A.H. Jabbar and J.A. Muhsin, 2015. Effect of exhaust gas temperature on the performance of automobile adsorption airconditioner. Am. J. Eng. Applied Sci., 8: 575-581. DOI: 10.3844 /ajeassp.2015.575.581

Khalil, R., 2015. Credibility of 3D volume computation using GIS for pit excavation and roadway constructions. Am. J. Eng. Applied Sci., 8: 434-442. DOI: 10.3844 /ajeassp.2015.434.442

Kamble, V.G. and N. Kumar, 2016. Fabrication and tensile property analysis of polymer matrix composites of graphite and silicon carbide as fillers. Am. J. Eng. Applied Sci., 9: 17-30. DOI: 10.3844/ajeassp.2016.17.30

Kazakov, V.V., V.I. Yusupov, V.N. Bagratashvili, A.I. Pavlikov and V.A. Kamensky, 2016. Control of bubble formation at the optical fiber tip by analyzing ultrasound acoustic waves. Am. J. Eng. Applied Sci., 9: 921-927. DOI: 10.3844/ajeassp.2016.921.927

Kechiche, O.B.H.B., H.B.A. Sethom, H. Sammoud and I.S. Belkhodja, 2011. Optimized high-frequency signal injection based permanent magnet synchronous motor rotor position estimation applied to washing machines. Am. J. Eng. Applied Sci., 4: 390-399. DOI: 10.3844/ajeassp.2011.390.399

Kuli, I., T.M. Abu-Lebdeh, E.H. Fini and S.A. Hamoush, 2016. The use of nano-silica for improving mechanical properties of hardened cement paste. Am. J. Eng. Applied Sci., 9: 146-154. DOI: 10.3844 /ajeassp.2016.146.154

Kumar, N.D., R.D. Ravali and PR. Srirekha, 2015. Design and realization of pre-amplifier and filters for on-board radar system. Am. J. Eng. Applied Sci., 8: 689-701. DOI: 10.3844/ajeassp.2015.689.701

Kunanoppadon, J., 2010. Thermal efficiency of a combined turbocharger set with gasoline engine. Am. J. Eng. Applied Sci., 3: 342-349. DOI: 10.3844 /ajeassp.2010.342.349 
Kwon, S., Y. Tani, H. Okubo and T. Shimomura, 2010. Fixed-star tracking attitude control of spacecraft using single-gimbal control moment gyros. Am. J. Eng. Applied Sci., 3: 49-55.

DOI: 10.3844 /ajeassp.2010.49.55

Lamarre, A., E.H. Fini and T.M. Abu-Lebdeh, 2016. Investigating effects of water conditioning on the adhesion properties of crack sealant. Am. J. Eng. Applied Sci., 9: 178-186. DOI: 10.3844/ajeassp.2016.178.186

Lee, B.J., 2013. Geometrical derivation of differential kinematics to calibrate model parameters of flexible manipulator. Int. J. Adv. Robotic Sys. DOI: $10.5772 / 55592$

Li, R., B. Zhang, S. Xiu, H. Wang and L. Wang et al., 2015. Characterization of solid residues obtained from supercritical ethanol liquefaction of swine manure. Am. J. Eng. Applied Sci., 8: 465- 470. DOI: 10.3844/ajeassp.2015.465.470

Lin, W., B. Li, X. Yang and D. Zhang, 2013. Modelling and control of inverse dynamics for a 5-DOF parallel kinematic polishing machine. Int. J. Adv. Robotic Sys. DOI: 10.5772/54966

Liu, H., W. Zhou, X. Lai and S. Zhu, 2013. An efficient inverse kinematic algorithm for a PUMA560structured robot manipulator. IJARS. DOI: $10.5772 / 56403$

Lubis, Z., A.N. Abdalla, Mortaza and R. Ghon, 2009. Mathematical modeling of the three phase induction motor couple to DC motor in hybrid electric vehicle. Am. J. Eng. Applied Sci., 2: 708-712. DOI: 10.3844/ajeassp.2009.708.712

Madani, D.A. and A. Dababneh, 2016. Rapid entire body assessment: A literature review. Am. J. Eng. Applied Sci., 9: 107-118.

DOI: 10.3844/ajeassp.2016.107.118

Malomar, G.E.B., A. Gueye, C. Mbow, V.B. Traore and A.C. Beye, 2016. Numerical study of natural convection in a square porous cavity thermally modulated on both side walls. Am. J. Eng. Applied Sci., 9: 591-598.

DOI: 10.3844/ajeassp.2016.591.598

Mansour, M.A.A., 2016. Developing an anthropometric database for Saudi students and comparing Saudi dimensions relative to Turkish and Iranian peoples. Am. J. Eng. Applied Sci., 9: 547-557. DOI: 10.3844 /ajeassp.2016.547.557

Maraveas, C., Z.C. Fasoulakis and K.D. Tsavdaridis, 2015. A review of human induced vibrations on footbridges. Am. J. Eng. Applied Sci., 8: 422-433. DOI: 10.3844/ajeassp.2015.422.433

Marghany, M. and M. Hashim, 2009. Robust of doppler centroid for mapping sea surface current by using radar satellite data. Am. J. Eng. Applied Sci., 2: 781-788. DOI: 10.3844/ajeassp.2009.781.788
Martins, F.R., A.R. Gonçalves and E.B. Pereira, 2016. Observational study of wind shear in northeastern Brazil. Am. J. Eng. Applied Sci., 9: 484-504. DOI: 10.3844/ajeassp.2016.484.504

Marzuki, M.A.L.B., M.H. Abd Halim and A.R.N. Mohamed, 2015. Determination of natural frequencies through modal and harmonic analysis of space frame race car chassis based on ANSYS. Am. J. Eng. Applied Sci., 8: 538-548. DOI: 10.3844 /ajeassp.2015.538.548

Mavukkandy, M.O., S. Chakraborty, T. Abbasi and S.A. Abbasi, 2016. A clean-green synthesis of platinum nanoparticles utilizing a pernicious weed lantana (Lantana Camara). Am. J. Eng. Applied Sci., 9: 8490. DOI: 10.3844/ajeassp.2016.84.90

Minghini, F., N. Tullini and F. Ascione, 2016. Updating Italian design guide CNR DT-205/2007 in view of recent research findings: Requirements for pultruded FRP profiles. Am. J. Eng. Applied Sci., 9: 702-712. DOI: 10.3844/ajeassp.2016.702.712

Moezi, N., D. Dideban and A. Ketabi, 2008. A novel integrated SET based inverter for nano power electronic applications. Am. J. Eng. Applied Sci., 1: 219-222. DOI: 10.3844/ajeassp.2008.219.222

Mohamed, M.A., A.Y. Tuama, M. Makhtar, M.K. Awang and M. Mamat, 2016. The effect of RSA exponential key growth on the multi-core computational resource. Am. J. Eng. Applied Sci., 9: 1054-1061.

DOI: 10.3844/ajeassp.2016.1054.1061

Mohan, K.S.R., P. Jayabalan and A. Rajaraman, 2012. Properties of fly ash based coconut fiber composite. Am. J. Eng. Applied Sci., 5: 29-34.

DOI: 10.3844/ajeassp.2012.29.34

Mohseni, E. and K.D. Tsavdaridis, 2016. Effect of nanoalumina on pore structure and durability of class $f$ fly ash self-compacting mortar. Am. J. Eng. Applied Sci., 9: 323-333.

DOI: 10.3844/ajeassp.2016.323.333

Momani, M.A., T.A. Al Smadi, FM. Al Taweel and K.A. Ghaidan, 2011. GPS ionospheric total electron content and scintillation measurements during the October 2003 magnetic storm. Am. J. Eng. Applied Sci., 4: 301-306. DOI: 10.3844 /ajeassp.2011.301.306

Momta, P.S., J.O. Omoboh and M.I. Odigi, 2015. Sedimentology and depositional environment of D2 sand in part of greater ughelli depobelt, onshore Niger Delta, Nigeria. Am. J. Eng. Applied Sci., 8: 556-566. DOI: 10.3844 /ajeassp.2015.556.566

Mondal, R., S. Sahoo and C.S. Rout, 2016. Mixed nickel cobalt manganese oxide nanorods for supercapacitor application. Am. J. Eng. Applied Sci., 9: 540-546. DOI: 10.3844/ajeassp.2016.540.546 
Montgomery, J., T.M. Abu-Lebdeh, S.A. Hamoush and M. Picornell, 2016. Effect of nano-silica on the compressive strength of harden cement paste at different stages of hydration. Am. J. Eng. Applied Sci., 9: 166-177.

DOI: 10.3844 /ajeassp.2016.166.177

Moretti, M.L., 2015. Seismic design of masonry and reinforced concrete infilled frames: A comprehensive overview. Am. J. Eng. Applied Sci., 8: 748-766. DOI: 10.3844/ajeassp.2015.748.766

Morse, A., M.M. Mansfield, R.M. Alley, H.A. Kerr and R.B. Bucinell, 2016b. Traction enhancing products affect maximum torque at the shoe-floor interface: A potential increased risk of ACL injury. Am. J. Eng. Applied Sci., 9: 889-893.

DOI: 10.3844 /ajeassp.2016.889.893

Moubarek, T. and A. Gharsallah, 2016. A six-port reflectometer calibration using Wilkinson power divider. Am. J. Eng. Applied Sci., 9: 274-280. DOI: 10.3844/ajeassp.2016.274.280

Nabilou, A., 2016a. Effect of parameters of selection and replacement drilling bits based on geo-mechanical factors: (Case study: Gas and oil reservoir in the Southwest of Iran). Am. J. Eng. Applied Sci., 9: 380-395. DOI: 10.3844/ajeassp.2016.380.395

Nabilou, A., 2016b. Study of the parameters of Steam Assisted Gravity Drainage (SAGD) method for enhanced oil recovery in a heavy oil fractured carbonate reservoir. Am. J. Eng. Applied Sci., 9: 647-658. DOI: 10.3844/ajeassp.2016.647.658

Nachiengtai, T., W. Chim-Oye, S. Teachavorasinskun and W. Sa-Ngiamvibool, 2008. Identification of shear band using elastic shear wave propagation. Am. J. Eng. Applied Sci., 1: 188-191.

DOI: 10.3844/ajeassp.2008.188.191

Nahas, R. and S.P. Kozaitis, 2014. Metric for the fusion of synthetic and real imagery from multimodal sensors. Am. J. Eng. Applied Sci., 7: 355-362. DOI: 10.3844/ajeassp.2014.355.362

Nandhakumar, S., V. Selladurai and S. Sekar, 2009. Numerical investigation of an industrial robot arm control problem using haar wavelet series. Am. J. Eng. Applied Sci., 2: 584-589.

DOI: 10.3844/ajeassp.2009.584.589

Ng, K.C., M.Z. Yusoff, K. Munisamy, H. Hasini and N.H. Shuaib, 2008. Time-marching method for computations of high-speed compressible flow on structured and unstructured grid. Am. J. Eng. Applied Sci., 1: 89-94.

DOI: 10.3844/ajeassp.2008.89.94

Obaiys, S.J., Z. Abbas, N.M.A. Nik Long, A.F. Ahmad and A. Ahmedov et al., 2016. On the general solution of first-kind hypersingular integral equations. Am. J. Eng. Applied Sci., 9: 195-201. DOI: 10.3844/ajeassp.2016.195.201
Odeh, S., R. Faqeh, L. Abu Eid and N. Shamasneh, 2009. Vision-based obstacle avoidance of mobile robot using quantized spatial model. Am. J. Eng. Applied Sci., 2: 611-619.

DOI: 10.3844/ajeassp.2009.611.619

Ong, A.T., A. Mustapha, Z.B. Ibrahim, S. Ramli and B.C. Eong, 2015. Real-time automatic inspection system for the classification of PCB flux defects. Am. J. Eng. Applied Sci., 8: 504-518. DOI: 10.3844 /ajeassp.2015.504.518

Opafunso, Z.O., I.I. Ozigis and I.A. Adetunde, 2009. Pneumatic and hydraulic systems in coal fluidized bed combustor. Am. J. Eng. Applied Sci., 2: 88-95. DOI: 10.3844 /ajeassp.2009.88.95

Orlando, N. and E. Benvenuti, 2016. Advanced XFEM simulation of pull-out and debonding of steel bars and FRP-reinforcements in concrete beams. Am. J. Eng. Applied Sci., 9: 746-754. DOI: 10.3844 /ajeassp.2016.746.754

Pannirselvam, N., P.N. Raghunath and K. Suguna, 2008. Neural network for performance of glass fibre reinforced polymer plated RC beams. Am. J. Eng. Applied Sci., 1: 82-88.

DOI: 10.3844 /ajeassp.2008.82.88

Pattanasethanon, S., 2010. The solar tracking system by using digital solar position sensor. Am. J. Eng. Applied Sci., 3: 678-682.

DOI: 10.3844 /ajeassp.2010.678.682

Pérez-de León, G., V.E. Lamberti, R.D. Seals, T.M. Abu-Lebdeh and S.A. Hamoush, 2016. Gas atomization of molten metal: Part I. Numerical modeling conception. Am. J. Eng. Applied Sci., 9: 303-322. DOI: 10.3844/ajeassp.2016.303.322

Padula, F. and V. Perdereau, 2013. An on-line path planner for industrial manipulators. Int. J. Adv. Robotic Sys. DOI: 10.5772/55063

Perumaal, S. and N. Jawahar, 2013. Automated trajectory planner of industrial robot for pick-andplace task. IJARS. DOI: 10.5772/53940

Petrescu, F. and R. Petrescu, 1995a. Contributions to optimization of the polynomial motion laws of the stick from the internal combustion engine distribution mechanism. Bucharest, 1: 249-256.

Petrescu, F. and R. Petrescu, 1995b. Contributions to the synthesis of internal combustion engine distribution mechanisms. Bucharest, 1: 257-264.

Petrescu, F. and R. Petrescu, 1997a. Dynamics of cam mechanisms (exemplified on the classic distribution mechanism). Bucharest, 3: 353-358.

Petrescu, F. and R. Petrescu, 1997b. Contributions to the synthesis of the distribution mechanisms of internal combustion engines with a Cartesian coordinate method. Bucharest, 3: 359-364. 
Petrescu, F. and R. Petrescu, 1997c. Contributions to maximizing polynomial laws for the active stroke of the distribution mechanism from internal combustion engines. Bucharest, 3: 365-370.

Petrescu, F. and R. Petrescu, 2000a. Synthesis of distribution mechanisms by the rectangular (Cartesian) coordinate method. Proceedings of the 8th National Conference on International Participation, (CIP' 00), Craiova, Romania, pp: 297-302.

Petrescu, F. and R. Petrescu, 2000b. The design (synthesis) of cams using the polar coordinate method (triangle method). Proceedings of the 8th National Conference on International Participation, (CIP' 00), Craiova, Romania, pp: 291-296.

Petrescu, F. and R. Petrescu, 2002a. Motion laws for cams. Proceedings of the International Computer Assisted Design, National Symposium with Participation, (SNP' 02), Braşov, pp: 321-326.

Petrescu, F. and R. Petrescu, 2002b. Camshaft dynamics elements. Proceedings of the International Computer Assisted Design, National Participation Symposium, (SNP' 02), Braşov, pp: 327-332.

Petrescu, F. and R. Petrescu, 2003. Some elements regarding the improvement of the engine design. Proceedings of the National Symposium, Descriptive Geometry, Technical Graphics and Design, (GTD' 03), Braşov, pp: 353-358.

Petrescu, F. and R. Petrescu, 2005a. The cam design for a better efficiency. Proceedings of the International Conference on Engineering Graphics and Design, (EGD' 05), Bucharest, pp: 245-248.

Petrescu, F. and R. Petrescu, 2005b. Contributions at the dynamics of cams. Proceedings of the 9th IFToMM International Symposium on Theory of Machines and Mechanisms, (TMM' 05), Bucharest, Romania, pp: 123-128.

Petrescu, F. and R. Petrescu, 2005c. Determining the dynamic efficiency of cams. Proceedings of the 9th IFToMM International Symposium on Theory of Machines and Mechanisms, (TMM' 05), Bucharest, Romania, pp: 129-134.

Petrescu, F. and R. Petrescu, 2005d. An original internal combustion engine. Proceedings of the 9th IFToMM International Symposium on Theory of Machines and Mechanisms, (TMM' 05), Bucharest, Romania, pp: 135-140.

Petrescu, F. and R. Petrescu, 2005e. Determining the mechanical efficiency of Otto engine's mechanism. Proceedings of the 9th IFToMM International Symposium on Theory of Machines and Mechanisms, (TMM 05), Bucharest, Romania, pp: 141-146.

Petrescu, F.I. and R.V. Petrescu, 2011a. Mechanical Systems, Serial and Parallel (Romanian). 1st Edn., LULU Publisher, London, UK, pp: 124.
Petrescu, F.I.T. and RV. Petrescu, 2011b. Trenuri Planetare. 1st Edn., Createspace Independent Pub., ISBN-13: 978-1468030419, pp: 104.

Petrescu, F.I. and R.V. Petrescu, 2012a. Kinematics of the planar quadrilateral mechanism. ENGEVISTA, 14: 345-348.

Petrescu, F.I. and R.V. Petrescu, 2012b. MecatronicaSisteme Seriale si Paralele. 1st Edn., Create Space Publisher, USA, pp: 128.

Petrescu, F.I. and R.V. Petrescu, 2013a. Cinematics of the 3R dyad. ENGEVISTA, 15: 118-124.

Petrescu, F.I.T. and R.V. Petrescu, 2013b. Forces and efficiency of cams. Int. Rev. Mech. Eng., 7: 507-511.

Petrescu, F.I.T. and R.V. Petrescu, 2013c. Cams with high efficiency. Int. Rev. Mech. Eng., 7: 599-606.

Petrescu, F.I.T. and R.V. Petrescu, 2013d. An algorithm for setting the dynamic parameters of the classic distribution mechanism. Int. Rev. Modell. Simulat., 6: 1637-1641.

Petrescu, F.I.T. and R.V. Petrescu, 2013e. Dynamic synthesis of the rotary cam and translated tappet with roll. Int. Rev. Modell. Simulat., 6: 600-607.

Petrescu, F.I.T. and R.V. Petrescu, 2014a. Parallel moving mechanical systems. Independent J. Manage. Product., 5: 564-580.

Petrescu, F.I.T. and R.V. Petrescu, 2014b. Cam gears dynamics in the classic distribution. Independent $\mathrm{J}$. Manage. Product., 5: 166-185.

Petrescu, F.I.T. and R.V. Petrescu, 2014c. Highefficiency gears synthesis by avoid the interferences. Independent J. Manage. Product., 5: 275-298.

Petrescu, F.I.T. and R.V. Petrescu, 2014d. Gear design. J. ENGEVISTA, 16: 313-328.

Petrescu, F.I.T. and R.V. Petrescu, 2014e. Kinetostatic of the $3 \mathrm{R}$ dyad (or $2 \mathrm{R}$ module). J. ENGEVISTA, 16: 314-321.

Petrescu, F.I.T. and R.V. Petrescu, 2014f. Balancing Otto engines. Int. Rev. Mech. Eng., 8: 473-480.

Petrescu, F.I.T. and R.V. Petrescu, 2014g. Machine equations to the classical distribution. Int. Rev. Mech. Eng., 8: 309-316.

Petrescu, F.I.T. and R.V. Petrescu, 2014h. Forces of internal combustion heat engines. Int. Rev. Modell. Simulat., 7: 206-212.

Petrescu, F.I.T. and R.V. Petrescu, 2014i. Determination of the yield of internal combustion thermal engines. Int. Rev. Mech. Eng., 8: 62-67.

Petrescu, F.I.T. and R.V. Petrescu, 2015a. Forces at the main mechanism of a railbound forging manipulator. Independent J. Manage. Product., 6: 904-921.

Petrescu, F.I.T. and R.V. Petrescu, 2015b. Kinematics at the main mechanism of a railbound forging manipulator. Independent J. Manage. Product., 6: 711-729. 
Petrescu, F.I.T. and R.V. Petrescu, 2015c. Machine motion equations. Independent J. Manage. Product., 6: 773-802.

Petrescu F.I.T. and R.V. Petrescu, 2015d. Presenting a railbound forging manipulator. Applied Mech. Mater., 762: 219-224.

Petrescu, F.I.T. and R.V. Petrescu, 2015e. About the anthropomorphic robots. J. ENGEVISTA, 17: 1-15.

Petrescu, F.I. and R.V. Petrescu, 2016a. Parallel moving mechanical systems kinematics. ENGEVISTA, 18: 455-491.

Petrescu, F.I. and R.V. Petrescu, 2016b. Direct and inverse kinematics to the anthropomorphic robots. ENGEVISTA, 18: 109-124.

Petrescu, F.I. and R.V. Petrescu, 2016c. Dynamic cinematic to a structure 2R. Revista Geintec-Gestao Inovacao E Tecnol., 6: 3143-3154.

Petrescu, FIT. and R.V. Petrescu, 2016d. An Otto engine dynamic model. Independent J. Manage. Product., 7: 038-048.

Petrescu, R.V., R. Aversa, A. Apicella and F.I. Petrescu, 2016. Future medicine services robotics. Am. J. Eng. Applied Sci., 9: 1062-1087. DOI: 10.3844/ajeassp.2016.1062.1087

Petrescu, F.I., B. Grecu, A. Comanescu and R.V. Petrescu, 2009. Some mechanical design elements. Proceeding of the International Conference on Computational Mechanics and Virtual Engineering, (MVE' 09), Braşov, pp: 520-525.

Petrescu, F.I.T., 2011. Teoria Mecanismelor si a Masinilor: Curs Si Aplicatii. 1st Edn., CreateSpace Independent Publishing Platform. ISBN-10: 1468015826. pp: 432.

Petrescu, F.I.T., 2015a. Geometrical synthesis of the distribution mechanisms. Am. J. Eng. Applied Sci., 8: 63-81. DOI: 10.3844/ajeassp.2015.63.81

Petrescu, F.I.T., 2015b. Machine motion equations at the internal combustion heat engines. Am. J. Eng. Applied Sci., 8: 127-137.

DOI: 10.3844/ajeassp.2015.127.137

Petrescu, F.I.T., A. Apicella, A. Raffaella, R.V. Petrescu and J.K. Calautit et al., 2016. Something about the mechanical moment of Inertia. Am. J. Applied Sci., 13: $1085-1090$.

DOI: 10.3844/ajassp.2016.1085.1090

Petrescu, R.V., R. Aversa, B. Akash, R. Bucinell and J. Corchado et al., 2017a. Yield at thermal engines internal combustion. Am. J. Eng. Applied Sci., 10: 243-251. DOI: 10.3844/ajeassp.2017.243.251

Petrescu, R.V., R. Aversa, B. Akash, B. Ronald and J. Corchado et al., 2017b. Velocities and accelerations at the 3R mechatronic systems. Am. J. Eng. Applied Sci., 10: 252-263.

DOI: 10.3844 /ajeassp.2017.252.263
Petrescu, R.V., R. Aversa, B. Akash, R. Bucinell and J. Corchado et al., 2017c. Anthropomorphic solid structures n-r kinematics. Am. J. Eng. Applied Sci., 10: 279-291. DOI: 10.3844/ajeassp.2017.279.291

Petrescu, R.V., R. Aversa, B. Akash, R. Bucinell and J. Corchado et al., 2017d. Inverse kinematics at the anthropomorphic robots, by a trigonometric method. Am. J. Eng. Applied Sci., 10: 394-411. DOI: 10.3844/ajeassp.2017.394.411

Petrescu, R.V., R. Aversa, B. Akash, R. Bucinell and J. Corchado et al., 2017e. Forces at internal combustion engines. Am. J. Eng. Applied Sci., 10: 382-393. DOI: 10.3844/ajeassp.2017.382.393

Petrescu, R.V., R. Aversa, B. Akash, R. Bucinell and J. Corchado et al., 2017f. Gears-Part I. Am. J. Eng. Applied Sci., 10: 457-472. DOI: 10.3844/ajeassp.2017.457.472

Petrescu, R.V., R. Aversa, B. Akash, R. Bucinell and J. Corchado et al., 2017g. Gears-part II. Am. J. Eng. Applied Sci., 10: 473-483. DOI: 10.3844/ajeassp.2017.473.483

Petrescu, R.V., R. Aversa, B. Akash, R. Bucinell and J. Corchado et al., 2017h. Cam-gears forces, velocities, powers and efficiency. Am. J. Eng. Applied Sci., 10: 491-505. DOI: 10.3844/ajeassp.2017.491.505

Petrescu, R.V., R. Aversa, B. Akash, R. Bucinell and J. Corchado et al., 2017i. Dynamics of mechanisms with cams illustrated in the classical distribution. Am. J. Eng. Applied Sci., 10: 551-567. DOI: 10.3844/ajeassp.2017.551.567

Petrescu, R.V., R. Aversa, B. Akash, R. Bucinell and J. Corchado et al., 2017j. Testing by non-destructive control. Am. J. Eng. Applied Sci., 10: 568-583. DOI: 10.3844 /ajeassp.2017.568.583

Petrescu, R.V., R. Aversa, A. Apicella and F.I.T. Petrescu, 2017k. Transportation engineering. Am. J. Eng. Applied Sci., 10: 685-702. DOI: 10.3844/ajeassp.2017.685.702

Petrescu, R.V., R. Aversa, S. Kozaitis, A. Apicella and F.I.T. Petrescu, 20171. The quality of transport and environmental protection, part I. Am. J. Eng. Applied Sci., 10: 738-755. DOI: 10.3844/ajeassp.2017.738.755

Petrescu, R.V., R. Aversa, B. Akash, R. Bucinell and J. Corchado et al., $2017 \mathrm{~m}$. Modern propulsions for aerospace-a review. J. Aircraft Spacecraft Technol., 1: 1-8. DOI: 10.3844/jastsp.2017.1.8

Petrescu, R.V., R. Aversa, B. Akash, R. Bucinell and J. Corchado et al., 2017n. Modern propulsions for aerospace-part II. J. Aircraft Spacecraft Technol., 1: 9-17. DOI: 10.3844/jastsp.2017.9.17

Petrescu, R.V., R. Aversa, B. Akash, R. Bucinell and J. Corchado et al., 2017o. History of aviation-a short review. J. Aircraft Spacecraft Technol., 1: 30-49. DOI: 10.3844 jastsp.2017.30.49 
Petrescu, R.V., R. Aversa, B. Akash, R. Bucinell and J. Corchado et al., 2017p. Lockheed martin-a short review. J. Aircraft Spacecraft Technol., 1: 50-68. DOI: 10.3844 jastsp.2017.50.68

Petrescu, R.V., R. Aversa, B. Akash, J. Corchado and F. Berto et al., 2017q. Our universe. J. Aircraft Spacecraft Technol., 1: 69-79.

DOI: $10.3844 /$ jastsp.2017.69.79

Petrescu, R.V., R. Aversa, B. Akash, J. Corchado and F. Berto et al., 2017r. What is a UFO? J. Aircraft Spacecraft Technol., 1: 80-90.

DOI: $10.3844 /$ jastsp.2017.80.90

Petrescu, R.V., R. Aversa, B. Akash, J. Corchado and F. Berto et al., 2017s. About bell helicopter FCX-001 concept aircraft-a short review. J. Aircraft Spacecraft Technol., 1: 91-96. DOI: 10.3844/jastsp.2017.91.96

Petrescu, R.V., R. Aversa, B. Akash, J. Corchado and F. Berto et al., 2017t. Home at airbus. J. Aircraft Spacecraft Technol., 1: 97-118. DOI: $10.3844 /$ jastsp.2017.97.118

Petrescu, R.V., R. Aversa, B. Akash, J. Corchado and F. Berto et al., 2017u. Airlander. J. Aircraft Spacecraft Technol., 1: 119-148. DOI: $10.3844 /$ jastsp.2017.119.148

Petrescu, R.V., R. Aversa, B. Akash, J. Corchado and F. Berto et al., 2017v. When boeing is dreaming-a review. J. Aircraft Spacecraft Technol., 1: 149-161. DOI: 10.3844 /jastsp.2017.149.161

Petrescu, R.V., R. Aversa, B. Akash, J. Corchado and F. Berto et al., 2017w. About Northrop Grumman. J. Aircraft Spacecraft Technol., 1: 162-185. DOI: $10.3844 /$ jastsp.2017.162.185

Petrescu, R.V., R. Aversa, B. Akash, J. Corchado and F. Berto et al., 2017x. Some special aircraft. J. Aircraft Spacecraft Technol., 1: 186-203. DOI: $10.3844 /$ jastsp.2017.186.203

Petrescu, R.V., R. Aversa, B. Akash, J. Corchado and F. Berto et al., 2017y. About helicopters. J. Aircraft Spacecraft Technol., 1: 204-223. DOI: $10.3844 /$ jastsp.2017.204.223

Petrescu, R.V., R. Aversa, B. Akash, F. Berto and A. Apicella et al., 2017z. The modern flight. J. Aircraft Spacecraft Technol., 1: 224-233. DOI: $10.3844 /$ jastsp.2017.224.233

Petrescu, R.V., R. Aversa, B. Akash, F. Berto and A. Apicella et al., 2017aa. Sustainable energy for aerospace vessels. J. Aircraft Spacecraft Technol., 1: 234-240. DOI: 10.3844/jastsp.2017.234.240

Petrescu, R.V., R. Aversa, B. Akash, F. Berto and A. Apicella et al., 2017ab. Unmanned helicopters. J. Aircraft Spacecraft Technol., 1: 241-248. DOI: $10.3844 /$ jastsp.2017.241.248

Petrescu, R.V., R. Aversa, B. Akash, F. Berto and A. Apicella et al., 2017ac. Project HARP. J. Aircraft Spacecraft Technol., 1: 249-257.

DOI: $10.3844 /$ jastsp.2017.249.257
Petrescu, R.V., R. Aversa, B. Akash, F. Berto and A. Apicella et al., 2017ad. Presentation of Romanian engineers who contributed to the development of global aeronautics-part I. J. Aircraft Spacecraft Technol., 1: 258-271. DOI: 10.3844 /jastsp.2017.258.271

Petrescu, R.V., R. Aversa, B. Akash, F. Berto and A. Apicella et al., 2017ae. A first-class ticket to the planet mars, please. J. Aircraft Spacecraft Technol., 1: 272-281. DOI: 10.3844/jastsp.2017.272.281

Petrescu, R.V., R. Aversa, A. Apicella, M.M. Mirsayar and S. Kozaitis et al., 2018a. NASA started a propeller set on board voyager 1 after 37 years of break. Am. J. Eng. Applied Sci., 11: 66-77. DOI: 10.3844 /ajeassp.2018.66.77

Petrescu, R.V., R. Aversa, A. Apicella, M.M. Mirsayar and S. Kozaitis et al., 2018b. There is life on mars? Am. J. Eng. Applied Sci., 11: 78-91. DOI: $10.3844 /$ ajeassp.2018.78.91

Petrescu, R.V., R. Aversa, A. Apicella and F.I.T. Petrescu, 2018c. Friendly environmental transport. Am. J. Eng. Applied Sci., 11: 154-165. DOI: 10.3844/ajeassp.2018.154.165

Petrescu, R.V., R. Aversa, B. Akash, T.M. Abu-Lebdeh and A. Apicella et al., 2018d. Buses running on gas. Am. J. Eng. Applied Sci., 11: 186-201. DOI: 10.3844/ajeassp.2018.186.201

Petrescu, R.V., R. Aversa, B. Akash, T.M. Abu-Lebdeh and A. Apicella et al., 2018e. Some aspects of the structure of planar mechanisms. Am. J. Eng. Applied Sci., 11: 245-259. DOI: 10.3844/ajeassp.2018.245.259

Petrescu, RV., R. Aversa, T.M. Abu-Lebdeh, A. Apicella and F.I.T. Petrescu, 2018f. The forces of a simple carrier manipulator. Am. J. Eng. Applied Sci., 11: 260-272. DOI: 10.3844/ajeassp.2018.260.272

Petrescu, RV., R. Aversa, T.M. Abu-Lebdeh, A. Apicella and F.I.T. Petrescu, 2018g. The dynamics of the otto engine. Am. J. Eng. Applied Sci., 11: 273-287. DOI: 10.3844/ajeassp.2018.273.287

Petrescu, RV., R. Aversa, T.M. Abu-Lebdeh, A. Apicella and F.I.T. Petrescu, 2018h. NASA satellites help us to quickly detect forest fires. Am. J. Eng. Applied Sci., 11: 288-296. DOI: 10.3844/ajeassp.2018.288.296

Petrescu, RV., R. Aversa, T.M. Abu-Lebdeh, A. Apicella and F.I.T. Petrescu, 2018i. Kinematics of a mechanism with a triad. Am. J. Eng. Applied Sci., 11: 297-308. DOI: 10.3844/ajeassp.2018.297.308

Petrescu, R.V., R. Aversa, A. Apicella and F.I.T. Petrescu, 2018j. Romanian engineering "on the wings of the wind". J. Aircraft Spacecraft Technol., 2: 1-18. DOI: 10.3844/jastsp.2018.1.18

Petrescu, R.V., R. Aversa, A. Apicella and F.I.T. Petrescu, 2018k. NASA Data used to discover eighth planet circling distant star. J. Aircraft Spacecraft Technol., 2: 19-30. DOI: $10.3844 /$ jastsp.2018.19.30 
Petrescu, R.V., R. Aversa, A. Apicella and F.I.T. Petrescu, 20181. NASA has found the most distant black hole. J. Aircraft Spacecraft Technol., 2: 31-39. DOI: $10.3844 /$ jastsp.2018.31.39

Petrescu, R.V., R. Aversa, A. Apicella and F.I.T. Petrescu, 2018m. Nasa selects concepts for a new mission to titan, the moon of saturn. J. Aircraft Spacecraft Technol., 2: 40-52.

DOI: 10.3844 /jastsp.2018.40.52

Petrescu, R.V., R. Aversa, A. Apicella and F.I.T. Petrescu, 2018n. NASA sees first in 2018 the direct proof of ozone hole recovery. J. Aircraft Spacecraft Technol., 2: 53-64. DOI: 10.3844/jastsp.2018.53.64

Pisello, A.L., G. Pignatta, C. Piselli, V.L. Castaldo and F. Cotana, 2016. Investigating the dynamic thermal behavior of building envelope in summer conditions by means of in-field continuous monitoring. Am. J. Eng. Applied Sci., 9: 505-519.

DOI: 10.3844/ajeassp.2016.505.519

Pourmahmoud, N., 2008. Rarefied gas flow modeling inside rotating circular cylinder. Am. J. Eng. Applied Sci., 1: 62-65. DOI: 10.3844/ajeassp.2008.62.65

Pravettoni, M., C.S.P. Lòpez and R.P. Kenny, 2016. Impact of the edges of a backside diffusive reflector on the external quantum efficiency of luminescent solar concentrators: Experimental and computational approach. Am. J. Eng. Applied Sci., 9: 53-63. DOI: 10.3844/ajeassp.2016.53.63

Qutbodin, K., 2010. Merging autopilot/flight control and navigation-flight management systems. Am. J. Eng. Applied Sci., 3: 629-630.

DOI: 10.3844 /ajeassp.2010.629.630

Rajbhandari, S., Z. Ghassemlooy and M. Angelova, 2011. The performance of a dual header pulse interval modulation in the presence of artificial light interferences in an indoor optical wireless communications channel with wavelet denoising. Am. J. Eng. Applied Sci., 4: 513-519.

DOI: 10.3844/ajeassp.2011.513.519

Rajput, R.S., S. Pandey and S. Bhadauria, 2016. Correlation of biodiversity of algal genera with special reference to the waste water effluents from industries. Am. J. Eng. Applied Sci., 9: 1127-1133. DOI: 10.3844/ajeassp.2016.1127.1133

Rajupillai, K., S. Palaniammal and K. Bommuraju, 2015. Computational intelligence and application of frame theory in communication systems. Am. J. Eng. Applied Sci., 8: 633-637.

DOI: 10.3844/ajeassp.2015.633.637

Raptis, K.G., G.A. Papadopoulos, T.N. Costopoulos and A.D. Tsolakis, 2011. Experimental study of load sharing in roller-bearing contact by caustics and photoelasticity. Am. J. Eng. Applied Sci., 4: 294300. DOI: 10.3844 /ajeassp.2011.294.300
Rama, G., D. Marinkovic and M. Zehn, 2016. Efficient co-rotational 3-node shell element. Am. J. Eng. Applied Sci., 9: 420-431.

DOI: 10.3844/ajeassp.2016.420.431

Rea, P. and E. Ottaviano, 2016. Analysis and mechanical design solutions for sit-to-stand assisting devices. Am. J. Eng. Applied Sci., 9: 1134-1143. DOI: 10.3844/ajeassp.2016.1134.1143

Rhode-Barbarigos, L., V. Charpentier, S. Adriaenssens and O. Baverel, 2015. Dialectic form finding of structurally integrated adaptive structures. Am. J. Eng. Applied Sci., 8: 443-454. DOI: 10.3844 /ajeassp.2015.443.454

Riccio, A., U. Caruso, A. Raimondo and A. Sellitto, 2016a. Robustness of XFEM method for the simulation of cracks propagation in fracture mechanics problems. Am. J. Eng. Applied Sci., 9: 599-610. DOI: 10.3844/ajeassp.2016.599.610

Riccio, A., R. Cristiano and S. Saputo, 2016b. A brief introduction to the bird strike numerical simulation. Am. J. Eng. Applied Sci., 9: 946-950. DOI: 10.3844/ajeassp.2016.946.950

Rich, F. and M.A. Badar, 2016. Statistical analysis of auto dilution Vs manual dilution process in inductively coupled plasma spectrometer tests. Am. J. Eng. Applied Sci., 9: 611-624. DOI: 10.3844/ajeassp.2016.611.624

Rohit, K. and S. Dixit, 2016. Mechanical properties of waste Biaxially Oriented Polypropylene metallized films (BOPP), LLDPE: LDPE films with sisal fibres. Am. J. Eng. Applied Sci., 9: 913-920. DOI: 10.3844 /ajeassp.2016.913.920

Rulkov, N.F., A.M. Hunt, P.N. Rulkov and A.G. Maksimov, 2016. Quantization of map-based neuronal model for embedded simulations of neurobiological networks in real-time. Am. J. Eng. Applied Sci., 9: 973-984. DOI: 10.3844/ajeassp.2016.973.984

Saikia, A. and N. Karak, 2016. Castor oil based epoxy/clay nanocomposite for advanced applications. Am. J. Eng. Applied Sci., 9: 31-40. DOI: 10.3844 /ajeassp.2016.31.40

Sallami, A., N. Zanzouri and M. Ksouri, 2016. Robust diagnosis of a DC motor by bond graph approach. Am. J. Eng. Applied Sci., 9: 432-438. DOI: 10.3844/ajeassp.2016.432.438

Samantaray, K.S., S. Sahoo and C.S. Rout, 2016. Hydrothermal synthesis of CuWO4-reduced graphene oxide hybrids and supercapacitor application. Am. J. Eng. Applied Sci., 9: 584-590. DOI: 10.3844/ajeassp.2016.584.590

Santos, F.A. and C. Bedon, 2016. Preliminary experimental and finite-element numerical assessment of the structural performance of SMAreinforced GFRP systems. Am. J. Eng. Applied Sci., 9: 692-701. DOI: 10.3844/ajeassp.2016.692.701 
Semin, A.R. Ismail and R.A. Bakar, 2009a. Combustion temperature effect of diesel engine convert to compressed natural gas engine. Am. J. Eng. Applied Sci., 2: 212-216.

DOI: 10.3844/ajeassp.2009.212.216

Semin, A.R. Ismail and R.A. Bakar, 2009b. Effect of diesel engine converted to sequential port injection compressed natural gas engine on the cylinder pressure Vs crank angle in variation engine speeds. Am. J. Eng. Applied Sci., 2: 154-159. DOI: 10.3844 /ajeassp.2009.154.159

Semin S., A.R. Ismail and R.A. Bakar, 2009c. Diesel engine convert to port injection $\mathrm{CNG}$ engine using gaseous injector nozzle multi holes geometries improvement: A review. Am. J. Eng. Applied Sci., 2: 268-278. DOI: 10.3844/ajeassp.2009.268.278

Semin and R.A. Bakar, 2008. A technical review of compressed natural gas as an alternative fuel for internal combustion engines. Am. J. Eng. Applied Sci., 1: 302-311. DOI: 10.3844/ajeassp.2008.302.311

Sepúlveda, J.A.M., 2016. Outlook of municipal solid waste in Bogota (Colombia). Am. J. Eng. Applied Sci., 9: 477-483. DOI: 10.3844/ajeassp.2016.477.483

Serebrennikov, A., D. Serebrennikov and Z. Hakimov, 2016. Polyethylene pipeline bending stresses at an installation. Am. J. Eng. Applied Sci., 9: 350-355. DOI: 10.3844/ajeassp.2016.350.355

Shanmugam, K., 2016. Flow dynamic behavior of fish oil/silver nitrate solution in mini-channel, effect of alkane addition on flow pattern and interfacial tension. Am. J. Eng. Applied Sci., 9: 236-250. DOI: 10.3844/ajeassp.2016.236.250

Shruti, 2016. Comparison in cover media under stegnography: Digital media by hide and seek approach. Am. J. Eng. Applied Sci., 9: 297-302. DOI: 10.3844/ajeassp.2016.297.302

Stavridou, N., E. Efthymiou and C.C. Baniotopoulos, 2015a. Welded connections of wind turbine towers under fatigue loading: Finite element analysis and comparative study. Am. J. Eng. Applied Sci., 8: 489-503. DOI: 10.3844/ajeassp.2015.489.503

Stavridou, N., E. Efthymiou and C.C. Baniotopoulos, $2015 \mathrm{~b}$. Verification of anchoring in foundations of wind turbine towers. Am. J. Eng. Applied Sci., 8: 717-729. DOI: 10.3844/ajeassp.2015.717.729

Suarez, L., T.M. Abu-Lebdeh, M. Picornell and S.A. Hamoush, 2016. Investigating the role of fly ash and silica fume in the cement hydration process. Am. J. Eng. Applied Sci., 9: 134-145.

DOI: 10.3844 /ajeassp.2016.134.145

Syahrullah, O.I. and N. Sinaga, 2016. Optimization and prediction of motorcycle injection system performance with feed-forward back-propagation method Artificial Neural Network (ANN). Am. J. Eng. Applied Sci., 9: 222-235.

DOI: 10.3844/ajeassp.2016.222.235
Sylvester, O., I. Bibobra and O.N. Ogbon, 2015a. Well test and PTA for reservoir characterization of key properties. Am. J. Eng. Applied Sci., 8: 638-647. DOI: 10.3844/ajeassp.2015.638.647

Sylvester, O., I. Bibobra and O. Augustina, 2015b. Report on the evaluation of Ugua $\mathrm{J} 2$ and $\mathrm{J} 3$ reservoir performance. Am. J. Eng. Applied Sci., 8: 678-688. DOI: 10.3844/ajeassp.2015.678.688

Taher, S.A., R. Hematti and M. Nemati, 2008. Comparison of different control strategies in GAbased optimized UPFC controller in electric power systems. Am. J. Eng. Applied Sci., 1: 45-52. DOI: 10.3844 /ajeassp.2008.45.52

Takeuchi, T., Y. Kinouchi, R. Matsui and T. Ogawa, 2015. Optimal arrangement of energy-dissipating members for seismic retrofitting of truss structures. Am. J. Eng. Applied Sci., 8: 455-464. DOI: 10.3844 /ajeassp.2015.455.464

Theansuwan, W. and K. Triratanasirichai, 2011. The biodiesel production from roast Thai sausage oil by transesterification reaction. Am. J. Eng. Applied Sci., 4: 130-132. DOI: 10.3844 /ajeassp.2011.130.132

Thongwan, T., A. Kangrang and S. Homwuttiwong, 2011. An estimation of rainfall using fuzzy setgenetic algorithms model. Am. J. Eng. Applied Sci., 4: 77-81. DOI: 10.3844/ajeassp.2011.77.81

Tourab, W., A. Babouri and M. Nemamcha, 2011. Experimental study of electromagnetic environment in the vicinity of high voltage lines. Am. J. Eng. Applied Sci., 4: 209-213. DOI: 10.3844 ajeassp.2011.209.213

Tsolakis, A.D. and K.G. Raptis, 2011. Comparison of maximum gear-tooth operating bending stresses derived from niemann's analytical procedure and the finite element method. Am. J. Eng. Applied Sci., 4: 350-354.

DOI: 10.3844/ajeassp.2011.350.354

Vernardos, S.M. and C.J. Gantes, 2015. Cross-section optimization of sandwich-type cylindrical wind turbine towers. Am. J. Eng. Applied Sci., 8: 471-480. DOI: 10.3844/ajeassp.2015.471.480

Wang, L., T. Liu, Y. Zhang and X. Yuan, 2016. A methodology for continuous evaluation of cloud resiliency. Am. J. Eng. Applied Sci., 9: 264-273. DOI: 10.3844 /ajeassp.2016.264.273

Wang, L., G. Wang and C.A. Alexander, 2015. Confluences among big data, finite element analysis and high-performance computing. Am. J. Eng. Applied Sci., 8: 767-774.

DOI: 10.3844/ajeassp.2015.767.774

Wang, J. and Y. Yagi, 2016. Fragment-based visual tracking with multiple representations. Am. J. Eng. Applied Sci., 9: 187-194.

DOI: 10.3844 /ajeassp.2016.187.194 
Waters, C., S. Ajinola and M. Salih, 2016. Dissolution sintering technique to create porous copper with sodium chloride using polyvinyl alcohol solution through powder metallurgy. Am. J. Eng. Applied Sci. 9: 155-165. DOI: 10.3844 /ajeassp.2016.155.165

Wessels, L. and H. Raad, 2016. Recent advances in point of care diagnostic tools: A review. Am. J. Eng. Applied Sci., 9: 1088-1095. DOI: 10.3844/ajeassp.2016.1088.1095

Yang, M.F. and Y. Lin, 2015. Process is unreliable and quantity discounts supply chain integration inventory model. Am. J. Eng. Applied Sci., 8: 602610. DOI: 10.3844 /ajeassp.2015.602.610

Yeargin, R., R. Ramey and C. Waters, 2016. Porosity analysis in porous brass using dual approaches. Am. J. Eng. Applied Sci., 9: 91-97. DOI: 10.3844/ajeassp.2016.91.97

You, M., X. Huang, M. Lin, Q. Tong and X. Li et al., 2016. Preparation of $\mathrm{LiCoMnO}_{4}$ assisted by hydrothermal approach and its electrochemical performance. Am. J. Eng. Applied Sci., 9: 396-405. DOI: 10.3844/ajeassp.2016.396.405

Zeferino, R.S., J.A.R. Ramón, E. de Anda Reyes, R.S. González and U. Pal, 2016. Large scale synthesis of $\mathrm{ZnO}$ nanostructures of different morphologies through solvent-free mechanochemical synthesis and their application in photocatalytic dye degradation. Am. J. Eng. Applied Sci., 9: 41-52. DOI: 10.3844 /ajeassp.2016.41.52

Zhao, B., 2013. Identification of multi-cracks in the gate rotor shaft based on the wavelet finite element method. Am. J. Eng. Applied Sci., 6: 309-319. DOI: 10.3844/ajeassp.2013.309.319

Zheng, H. and S. Li, 2016. Fast and robust maximum power point tracking for solar photovoltaic systems. Am. J. Eng. Applied Sci., 9: 755-769. DOI: 10.3844/ajeassp.2016.755.769

Zotos, I.S. and T.N. Costopoulos, 2009. On the use of rolling element bearings' models in Precision maintenance. Am. J. Eng. Applied Sci., 2: 344-352. DOI: 10.3844/ajeassp.2009.344.352

Zulkifli, R., K. Sopian, S. Abdullah and M.S. Takriff, 2008. Effect of pulsating circular hot air jet frequencies on local and average nusselt number. Am. J. Eng. Applied Sci., 1: 57-61. DOI: 10.3844/ajeassp.2008.57.61

Zulkifli, R., K. Sopian, S. Abdullah and M.S. Takriff, 2009. Experimental study of flow structures of circular pulsating air jet. Am. J. Eng. Applied Sci., 2: 171-175. DOI: 10.3844/ajeassp.2009.171.175
Zurfi, A. and J. Zhang, 2016a. Model identification and wall-plug efficiency measurement of white LED modules. Am. J. Eng. Applied Sci., 9: 412-419. DOI: 10.3844 /ajeassp.2016.412.419

Zurfi, A. and J. Zhang, 2016b. Exploitation of battery energy storage in load frequency control-a literature survey. Am. J. Eng. Applied Sci., 9: 1173-1188. DOI: 10.3844/ajeassp.2016.1173.1188

\section{Source of Figures:}

Petrescu and Petrescu, 2014 h-i

\section{Nomenclature}

$F_{m}: \quad$ is the motor force;

$F_{\tau}$ : is the tangential force, which produces the rotation of the element;

$F_{n}: \quad$ is the normal force, which is transmitted along the connecting rod;

$F_{R}$ : is the radial force, who press on the cylinder barrel in which guides the piston;

$F_{u}$ : The utile force, $F_{u}$, moves the piston (when the mechanism is in compressor system) and rotates the crank (when the mechanism is in motor system);

$F_{c}$ : $\quad$ is the force of compression and presses on the crankpin (B) and then on the crank and bearing (A);

$\varphi_{1}=\varphi:$ is the position angle of the crank;

$\varphi_{2}=\psi$. is the position angle of the rod (element 2 ), if the rod is considered from the point $C$;

$\varphi_{2}=\theta:$ is the position angle of the rod, if the $\operatorname{rod}$ is considered from the point $B$;

$\omega_{1}=\omega$ : the angular rotation speed of the crank (the motor shaft);

$l_{1}$ : $\quad$ is the length of the crank;

$l_{2}$ : $\quad$ is the length of the rod (the connecting rod);

$\lambda: \quad$ is the raport between $l_{1}$ and $l_{2}$;

$\eta_{i}^{c}: \quad$ is the instantly efficiency of the mechanism in the compressor system;

$\eta^{c}$ : $\quad$ is the mechanical yield of the mechanism in the compressor system;

$\eta_{i}^{m}: \quad$ is the instantly efficiency of the mechanism in the motor system;

$\eta^{m}: \quad$ is the mechanical yield of the mechanism in the motor system 